\title{
Effect of Ink and Pretreatment Conditions on Bioethanol and Biomethane Yields from Waste Banknote Paper
}

\author{
Omid Yazdani Aghmashhadi ${ }^{1, *, \dagger}$, Lisandra Rocha-Meneses ${ }^{2, *,+}{ }^{\oplus}$, Nemailla Bonturi ${ }^{3}{ }^{\circledR}$, Kaja Orupõld $^{4}(\mathbb{D}$, \\ Ghasem Asadpour ${ }^{1}{ }^{\mathbb{D}}$, Esmaeil Rasooly Garmaroody ${ }^{5}{ }^{(}$, Majid Zabihzadeh ${ }^{1}$ and Timo Kikas ${ }^{2} \mathbb{C}$
}

1 Department of Wood and Paper Engineering, Sari University of Agricultural Sciences and Natural Resources, Km 9 Farah Abad Road, Sari 66996-48181, Mazandaran Province, Iran; asadpur2002@yahoo.com (G.A.); m.zabihzadeh@sanru.ac.ir (M.Z.)

2 Institute of Technology, Chair of Biosystems Engineering, Estonian University of Life Sciences, Kreutzwaldi 56, 51006 Tartu, Estonia; Timo.Kikas@emu.ee

3 Institute of Technology, University of Tartu, 50411 Tartu, Estonia; Nemailla.Bonturi@ut.ee

4 Institute of Agricultural and Environmental Sciences, Estonian University of Life Sciences, Kreutzwaldi 5, 51006 Tartu, Estonia; Kaja.Orupold@emu.ee

5 Department of Bio-refinery Engineering, Faculty of New Technologies Engineering, Shahid Beheshti University, Zirab P.O. Box 47815-168, Mazandaran, Iran; e_rasooly@sbu.ac.ir

* Correspondence: omidyazdani29@yahoo.com (O.Y.A.); Lisandra.Meneses@emu.ee (L.R.-M.)

+ These authors contributed equally to this work.

check for

updates

Citation: Aghmashhadi, O.Y.; Rocha-Meneses, L.; Bonturi, N.; Orupõld, K.; Asadpour, G.; Garmaroody, E.R.; Zabihzadeh, M.; Kikas, T. Effect of Ink and Pretreatment Conditions on Bioethanol and Biomethane Yields from Waste Banknote Paper. Polymers 2021, 13, 239. https://doi.org/ $10.3390 /$ polym13020239

Received: 11 December 2020 Accepted: 8 January 2021 Published: 13 January 2021

Publisher's Note: MDPI stays neutral with regard to jurisdictional clai$\mathrm{ms}$ in published maps and institutional affiliations.

Copyright: $(\odot 2021$ by the authors. Licensee MDPI, Basel, Switzerland. This article is an open access article distributed under the terms and conditions of the Creative Commons Attribution (CC BY) license (https:// creativecommons.org/licenses/by/ $4.0 /)$.
Abstract: Waste banknote paper is a residue from the banking industry that cannot be recycled due to the presence of ink, microbial load and special coating that provides protection against humidity. As a result, waste banknote paper ends up being burned or buried, which brings environmental impacts, mainly caused by the presence of heavy metals in its composition. To minimize the environmental impacts that come from the disposal of waste banknote paper, this study proposes to produce value-added products (bioethanol and biogas) from waste banknote paper. For this, the effect of ink and pretreatment conditions on bioethanol and biomethane yields were analyzed. Waste banknote paper provided by the Central Bank of Iran was used. The raw material with ink (WPB) and without ink (WPD) was pretreated using sulfuric acid at different concentrations $(1 \%, 2 \%, 3 \%$, and $4 \%)$ and the nitrogen explosive decompression (NED) at different temperatures $\left(150{ }^{\circ} \mathrm{C}, 170{ }^{\circ} \mathrm{C}, 190{ }^{\circ} \mathrm{C}\right.$, and $\left.200{ }^{\circ} \mathrm{C}\right)$. The results show that the use of NED pretreatment in WPD resulted in the highest glucose concentration of all studies $(13 \pm 0.19 \mathrm{~g} / \mathrm{L})$. The acid pretreatment for WPB showed a correlation with the acid concentration. The highest ethanol concentration was obtained from the fermentation using WPD pretreated with NED $(6.36 \pm 0.72 \mathrm{~g} / \mathrm{L})$. The maximum methane yields varied between $136 \pm 5 \mathrm{~mol} / \mathrm{kg}$ TS ( $2 \%$ acid WPB) and $294 \pm 4 \mathrm{~mol} / \mathrm{kg}$ TS (3\% acid WPD). Our results show that the presence of ink reduces bioethanol and biogas yields and that the chemical-free NED pretreatment is more advantageous for bioethanol and biogas production than the acid pretreatment method. Waste banknote paper without ink is a suitable feedstock for sustainable biorefinery processes.

Keywords: anaerobic digestion; biofuel; biomass; cotton-based waste; closed-loop; lignocellulose

\section{Introduction}

The population growth and economic development have led to an increase in the production and consumption of materials and resources to satisfy global demand. However, this has also led to an increase in the amount of waste produced, such as municipal solid waste, industrial waste, and wastepaper [1,2]. Instead of being discarded after primary use, these residues can be used for the production of value-added products e.g., production of low-cost biofuels [3,4]. Among wastepaper, great attention has been paid to waste banknotes since they cannot be recycled due to their properties, such as the presence of 
pathogenic bacteria, heavy ink, and presence of formaldehyde melamine resin that provides protection against humidity and makes the digestion process more challenging [5-8].

The most common handling options for banknote paper are incineration or landfilling [9]. However, these strategies increase air pollution, and at the same time, pollute soils, and groundwater [10]. As a result, there is a search for more suitable and environmentally friendly handling options that can be applied to waste banknote paper. Banknote paper is to a large extent made of cotton and thus, has a high percentage of cellulose and low amounts of lignin in its composition, which makes it a suitable feedstock for the production of biofuels [7]. As banknote paper has high amounts of ink in its composition, a deinking process is required before its further treatment. The deinking process is composed of three sequential steps: pulping, soaking, and screening [7]. In the pulping stage, chemical and mechanical methods are used to separate ink and other non-fibrous contaminants from the fibrous material $[7,11,12]$. In the soaking stage, sodium hydroxide is used at high temperatures, followed by sieving and rinsing to separate and remove ink particles from the pulp [13]. Finally, in the screening process, a centrifugal cleaning is used to select and separate contaminants from the pulp fibers. Banknote paper has high amounts of alphacellulose in its composition ( 88 to $96 \%$ ) which makes it a suitable feedstock for bioethanol and biogas production. However, banknote paper has also a very crystalline structure that requires effective and harsh pretreatments methods to make the cellulose accessible for enzymatic hydrolysis $[7,14]$.

Bioethanol production is composed of four sequential steps: pretreatment, hydrolysis, fermentation, and distillation [15]. A wide variety of chemical, physical, biological, and physio-chemical pretreatment methods have been reported in the literature as effective in breaking down the plant cell wall and in making cellulose accessible to the enzymes [16]. Chemical pretreatment methods include acid, alkali, ionic liquids, and organosolv. Although chemical pretreatment methods have been widely used and are effective in dissolving lignin and hemicellulose, they are still expensive because of the high cost of chemicals [17]. Besides, several inhibitors, such as aliphatic carboxylic acids, phenolic compounds, and furans, are formed during chemical pretreatment, which may disrupt subsequent hydrolysis and fermentation processes [18,19]. Physical pretreatment methods include comminuting, irradiation, and freezing, while biological pretreatment methods use fungi, enzymes, or microorganisms to break down the lignin and hemicellulose bonds $[14,16]$. Combined physical and chemical pretreatment methods include ammonia fiber expansion, steam explosion (SE), carbon dioxide explosion $\left(\mathrm{CO}_{2}\right.$ explosion, and NED).

From all the pretreatment methods reported before, great attention has been paid to chemical-free pretreatment methods (e.g., $\mathrm{SE}, \mathrm{CO}_{2}$ explosion and NED) since these methods reduce environmental impacts and costs that incur when chemicals are used [20]. Steam explosion pretreatment method uses high pressure, saturated steam, and a rapid decompression to disrupt the plant cell wall and dissolve the hemicellulose [16]. $\mathrm{CO}_{2}$ explosion uses supercritical $\mathrm{CO}_{2}$ and low pretreatment temperatures to improve the digestibility of the biomass [14]. NED is one of the most effective physical and chemical pretreatments methods reported in the literature [21]. This pretreatment method used nitrogen and high temperatures to open the biomass structure more effectively. NED is economically and environmentally attractive because neither catalysts nor chemicals are used in the processes [20]. However, the principle of operation and the processes that take place during this pretreatment still need further research [19].

Waste paper, and particularly waste banknote paper can also be used as a raw material for biogas production since it is a cheap source of organic material [22]. Anaerobic digestion is a biological process that occurs in the absence of oxygen and uses micro-organisms to convert organic waste into high-quality nutrient-rich fertilizer and yield energy in the form of biogas [23]. Biogas is mainly composed of methane $(50-70 \%)$ and carbon dioxide (30-50\%). Minor compounds include vapor water, nitrogen, oxygen, hydrogen sulfide, and ammonia [24]. Biogas can be upgraded to produce biomethane. 
This study aims to investigate the potential of waste banknote paper (with and without ink) for bioethanol and biomethane production. For this purpose, two different pretreatment methods were applied-nitrogen explosive decompression and sulfuric acid pretreatment methods.

\section{Materials and Methods}

The production pathway utilized in this study to evaluate the potential of waste banknote paper for bioethanol and biogas production is illustrated in Figure 1.

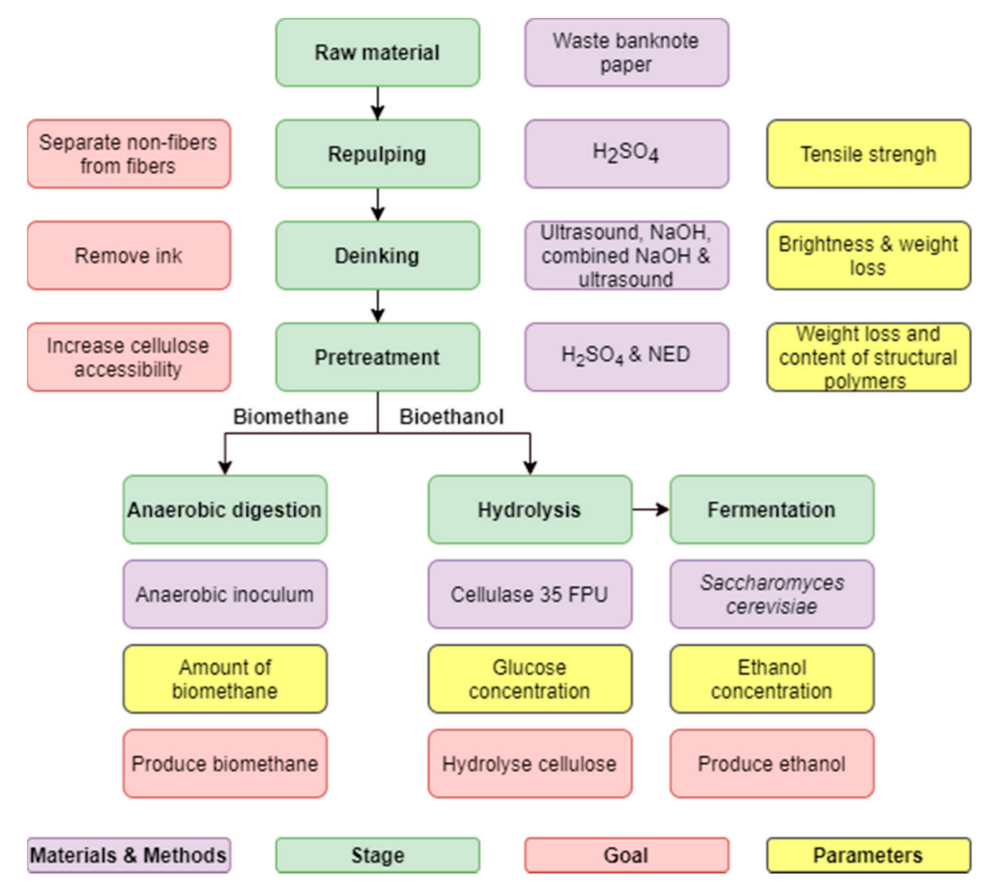

Figure 1. Production pathway utilized in this study to evaluate the potential of waste banknote paper for bioethanol and biomethane production.

\subsection{Raw Material}

Waste banknote paper obtained from the Central Bank of the Islamic Republic of Iran was used as a raw material in this study. After collection, the waste banknote paper was placed in the laboratory for $48 \mathrm{~h}$ to ensure equilibrium moisture content. After measuring the moisture content, the raw material was stored in bags until use.

\subsection{Repulping}

Wet strength is one of the main factors that should be taken into account when talking about waste banknote paper. This property of the paper is related to the presence of melamine formaldehyde, which is added to the banknote paper to increase its mechanical resistance and reduce water absorption. Therefore, the repulping process is required to break down melamine resin cross-links. In order to find the best conditions for the repulping process, the tensile strength was measured at different $\mathrm{pHs}$ (from $\mathrm{pH}=1$ to $\mathrm{pH}=12$ ). The lowest tensile strength indicates the best repulping conditions. The tensile strength was measured with a tensile tester, from FRANK-PTI GMBH company (Birkenau, Germany), following the standard method TAPPI T456 OM-15 [25]. For repulping, $0.5 \mathrm{~mL}$ of $98 \%$ sulfuric acid was added to $30 \mathrm{~g}$ of pulp, and distilled water was added to a $500 \mathrm{~mL}$ Erlenmeyer flask until a total working volume of $300 \mathrm{~mL}$ was reached. The samples were placed on a hot plate with a magnetic stirrer (M TOPS MS300HS, from Misung Scientific Co., Ltd., Gyeonggi-do, Korea) at $90{ }^{\circ} \mathrm{C}$ to $95^{\circ} \mathrm{C}$, and stirred at $500 \mathrm{rpm}$, for $90 \mathrm{~min}$ [26,27]. All the experiments were performed in triplicate. 


\subsection{Deinking}

After repulping, the samples were deinked using three deinking methods: chemical $(1 \%, 2 \%, 3 \%$, and $4 \%$ sodium hydroxide), ultrasonic (30Am, for $5 \mathrm{~min}$ ) and integrated ultrasonic and sodium hydroxide. In the ultrasonic deinking method, a Q700 Sonicator was used (from Qsonica, Newtown, USA). In the deinking process, $3 \mathrm{~g}$ (dry weight) of pulp was put in $100 \mathrm{~mL}$ Erlenmeyer flasks and treated at a temperature of $90-95{ }^{\circ} \mathrm{C}$. To increase the contact during the process, a mixer model FTDS 41 from Sci Finetech Co (Seoul, Korea) was used for $90 \mathrm{~min}$, at $500 \mathrm{rpm}$. In order to separate and remove the ink from the fibrous materials, the samples were washed using distilled water and a 200 mesh filter. After finishing the deinking process, a new paper was produced, for the weight loss, tensile strength, and brightness measurements. The brightness properties of the papers were measured according to the standard T452 om 08 using a Zb-a Powders brightness colorimeter testing from Hangzhou Zhibang Automation Technology Co. Ltd. (Hangzhou, China) $[7,26]$. The sodium hydroxide with a purity of $100 \%$ was from Merck Group (Darmstadt, Germany).

\subsection{Pretreatment}

\subsubsection{Chemical Pretreatment}

$\mathrm{H}_{2} \mathrm{SO}_{4}$ with $98 \%$ purity was used for the chemical pretreatment of the banknote pulp samples. The acid was added in different concentrations $(1 \%, 2 \%, 3 \%$, and $4 \%$ ) to Erlenmeyer flasks with 100g (dry weight) deinked waste banknote pulp (WPD) and non-de-inked waste banknote pulp (WPB). The samples were autoclaved for $30 \mathrm{~min}$ at $121{ }^{\circ} \mathrm{C}$. After the pretreatment, solid and liquid fractions of the samples were separated by centrifugation (Thermo Scientific Heraeus megacentrifuge, Waltham, USA) at 10,000 rpm for $30 \mathrm{~min}$. Samples from the solid fraction were left to dry at the atmospheric pressure and their weight loss was calculated.

\subsubsection{Physio-Chemical Pretreatment}

In NED pretreatment, $800 \mathrm{~mL}$ of distilled water was added to $100 \mathrm{~g}$ of dried WPD and WPB. The samples were mixed and pretreated at $150^{\circ} \mathrm{C}, 170^{\circ} \mathrm{C}, 190^{\circ} \mathrm{C}$, and $200{ }^{\circ} \mathrm{C}$, at a pressure of 30 bars using compressed nitrogen gas. After reaching the desired temperatures, the samples were cooled down to $80^{\circ} \mathrm{C}$ and the pressure was released from the vessel in an explosive manner [28]. After the pretreatment, solid and liquid fractions of the samples were separated by centrifugation (Thermo Scientific Heraeus megacentrifuge, Waltham, USA) at 10,000 rpm for $30 \mathrm{~min}$.

\subsection{Enzymatic Hydrolysis}

Pretreated WPD and WPB samples from the solid fraction were used to make a broth with $2.5 \%$ dry matter content that was further used for the enzymatic hydrolysis. The enzyme complex Accellerase 1500 (from DuPont de Nemours) was used at a ratio of $0.3 \mathrm{~mL}$ per $\mathrm{g}$ of biomass. Distilled water was added to the flasks to obtain a total working volume of $200 \mathrm{~mL}$. The hydrolysis took place for $72 \mathrm{~h}$, at a temperature of $50{ }^{\circ} \mathrm{C}$, under constant stirring in the orbital shaker (IKA ${ }^{\circledR}$-Werke GmbH \& Co. KG, Staufen im Breisgau, Germany) [18]. After the hydrolysis, the solid and liquid fractions of the samples were separated by centrifugation (Thermo Scientific Heraeus megacentrifuge, Waltham, USA) at 10,000 rpm for $30 \mathrm{~min}$. All the experiments were performed in triplicate.

\subsection{Fermentation}

Liquid samples that were obtained from the hydrolysis stage were further fermented using the yeast Saccharomyces cerevisiae. This yeast was added to the samples from the liquid fraction at the ratio of $0.025 \mathrm{~g} / \mathrm{g}$. The fermentation process lasted 7 days and it was carried out at $25^{\circ} \mathrm{C}$ [20]. 


\subsection{Biomethane Potential}

The biomethane potential (BMP) test used in this article is based on an adapted version of the protocol reported by Angelidaki et al. [29]. The inoculum was obtained from Tartu municipal wastewater treatment plant (Estonia), sieved through $2 \mathrm{~mm}$ mesh and pre-incubated for 4 days at $36{ }^{\circ} \mathrm{C}$ for degasification, before use [24]. The experiments were carried out in $575 \mathrm{~mL}$ plasma bottles with a working volume of $300 \mathrm{~mL}$ using the substrate to inoculum volatile solids (VS) ratio of 0.25 . The blank test (just inoculum without substrate) was included to study the biogas and methane production of the inoculum, which later was subtracted from that of the samples with the substrate. The test bottles were flushed with $\mathrm{N}_{2}$ to assure anaerobic conditions. The BMP tests were performed at $36^{\circ} \mathrm{C}$ in the lab incubator (Memmert $\mathrm{GmbH}+\mathrm{Co}$. KG, Schwabach, Germany) for 32 days (up until the methane content was constant). The experiments were carried out in triplicate. During BMP test the pressure in the headspace of test bottles was measured with pressure meter BMP-Testsystem WAL (WAL Mess- und Regelsysteme GmbH).

\subsection{Chemical Analysis}

The neutral detergent fiber (NDF), acid detergent fiber (ADF) and acid detergent lignin (ADL) were determined using an ANKOM 2000 I, fiber Analyzer (ANKOM Technology Corporation, NY 14502, USA).

The dry matter content (TS) was analyzed with a moisture analyzer Ohaus MB 45. The volatile solids (VS) were analyzed as loss on ignition at $550{ }^{\circ} \mathrm{C}$. The $\mathrm{pH}$ of the samples before and after pretreatment, hydrolysis, and fermentation was measured using a pH meter, model SevenCompact pH/Ion S220 from Mettler-Toledo AG (Schwerzenbach, Switzerland).

Glucose, glycerol, acetic acid, and ethanol were quantified by HPLC (LC-2030C Plus, Shimadzu, Kyoto, Japan) equipped with a refractive index detector (RID-20A, Shimadzu, Kyoto, Japan) using a Rezex ROA Organic Acid column (Phenomenex, Torrance, CA, USA) column at $45{ }^{\circ} \mathrm{C}$, and isocratic elution at $0.6 \mathrm{~mL} / \mathrm{min}$ of $5 \mathrm{mmol} / \mathrm{L} \mathrm{H}_{2} \mathrm{SO}_{4}$.

The quantification of methane in the produced biogas was done by gas chromatography (CP-4900 Micro-GC, from Varian Inc., Palo Alto, USA).

\subsection{Calculations}

The hydrolysis and fermentation efficiency were calculated based on Equation 1 and Equation (2), respectively [30].

$$
\begin{aligned}
\mathrm{E}_{\mathrm{HY}} & =\frac{\mathrm{m}_{\text {glc }}}{\mathrm{m}_{\text {cel }} \cdot 1 \cdot 11} \cdot 100 \% \\
\mathrm{E}_{\mathrm{F}} & =\frac{\mathrm{C}_{\text {eth }}}{\mathrm{C}_{\text {glc }} \cdot 0 \cdot 51} \cdot 100 \%
\end{aligned}
$$

where $\mathrm{E}_{\mathrm{HY}}$ is the hydrolysis efficiency, $\mathrm{m}_{\mathrm{glc}}$ the amount of glucose, $\mathrm{m}_{\mathrm{cel}}$, the amount of cellulose, 1.11 is the conversion factor of cellulose to glucose, $\mathrm{E}_{\mathrm{F}}$ is the fermentation efficiency, $\mathrm{C}_{\text {eth }}$ is the concentration of ethanol, $\mathrm{c}_{\mathrm{glc}}$ is the concentration of glucose, and 0.51 is the conversion factor of glucose to ethanol

The methane production was fitted and modelled in the software Graph-Pad Prism 5.0 with a non-linear regression model, using the equation Gompertz growth (Equation (3)).

$$
\mathrm{Y}=\mathrm{Y}_{\mathrm{M}} *\left(\frac{\mathrm{Y}_{0}}{\mathrm{Y}_{\mathrm{M}}}\right)^{\exp (-\mathrm{K} * \mathrm{X})}
$$

where $\mathrm{Y}$ is the cumulative methane produced (L/kg TS), $\mathrm{Y}_{\mathrm{M}}$ is the maximum population ( $\mathrm{L} / \mathrm{kg} \mathrm{TS}), \mathrm{Y}_{0}$ is the starting population ( $\mathrm{L} / \mathrm{kg}$ TS), $\mathrm{K}$ is the lag time $\left(\mathrm{d}^{-1}\right), \mathrm{X}$ is time (days). 


\subsection{Statistical Analysis}

The statistical analysis was performed in software Graph-Pad Prism 5.0. The normal distribution of the results was investigated using the Shapiro-Wilk normality test. For glucose and ethanol yields, the differences between the variables were studied using two-way ANOVA, followed by the post hoc test Tukey's multiple comparisons test. For biomethane yields, one-way ANOVA was used to investigate the statistically significant differences between the means of the different variables. The post hoc Dunn's multiple comparisons test. The results were statistically significant when $p \leq 0.05$ (confidence interval 95\%).

\section{Results}

The results of the deinking and repulping process are reported in a previous paper published by the authors [26].

\subsection{Chemical Composition}

The results of the chemical composition, ash content, moisture, $\mathrm{pH}$, and weight loss of WPB and WPD after being pretreated with NED and $\mathrm{H}_{2} \mathrm{SO}_{4}$ are reported in Table 1. The percentage of cellulose, hemicellulose, lignin, and ash for untreated WPB and WPD was $77-89 \%, 3-7 \%, 1-2 \%$, and $0.6-1 \%$, respectively. The cellulose content of WPB varied between $78 \%$ and $85 \%$, while for WPD samples it varied between $84 \%$ and $89 \%$. The percentage of hemicellulose differed from $1 \%$ and $6 \%$ for WPB samples, and from $1 \%$ to $8 \%$ for WPD samples. The amount of lignin and ash in all the samples was less than $2 \%$ and $1 \%$, respectively. The moisture content in all the samples varied between $3 \%$ and $9 \%$, and the $\mathrm{pH}$ between 5 and 6 . The weight loss of all the samples was $\leq 10.2 \%$. Statistically significant differences were found in the cellulose content of samples that were pretreated with acid $3 \%$ WPD and samples that were pretreated with acid 3\% WPB (Table A1, Appendix A).

Table 1. Hemicellulose, cellulose, lignin, ash, and moisture content of the samples after the pretreatment stage.

\begin{tabular}{|c|c|c|c|c|c|}
\hline Description & Cellulose (\%) & Hemicellulose (\%) & Lignin (\%) & $\mathrm{pH}$ & Weight Loss (\%) \\
\hline NED $150{ }^{\circ} \mathrm{C}$ WPB & $85 \pm 3$ & $6 \pm 3$ & $1 \pm 0.7$ & $5.5 \pm 0.3$ & 5.2 \\
\hline NED $170{ }^{\circ} \mathrm{C}$ WPB & $84 \pm 0.2$ & $4 \pm 2$ & $1 \pm 0.6$ & $5.5 \pm 0.2$ & 6.1 \\
\hline NED $190^{\circ} \mathrm{C}$ WPB & $78 \pm 5$ & $4 \pm 0.5$ & $0.9 \pm 0.0$ & $5.7 \pm 0.0$ & 6.7 \\
\hline NED $200{ }^{\circ} \mathrm{C}$ WPB & $83 \pm 1$ & $3 \pm 0.5$ & $0.6 \pm 0.0$ & $5.5 \pm 0.0$ & 6.3 \\
\hline Acid 1\% WPB & $85 \pm 1$ & $3 \pm 2$ & $0.7 \pm 0.0$ & $5.9 \pm 0.1$ & 6.2 \\
\hline Acid 2\% WPB & $83 \pm 0.6$ & $1 \pm 3$ & $0.6 \pm 0.0$ & $5.7 \pm 0.0$ & 9.4 \\
\hline Acid 3\% WPB & $70 \pm 7$ & $1 \pm 1$ & $0.7 \pm 0.0$ & $6.0 \pm 0.0$ & 10.2 \\
\hline Acid 4\% WPB & $79 \pm 4$ & $2 \pm 2$ & $0.6 \pm 0.2$ & $5.8 \pm 0.0$ & 9.7 \\
\hline NED $150^{\circ} \mathrm{C}$ WPD & $89 \pm 0.6$ & $8 \pm 0.0$ & $0.2 \pm 0.1$ & $5.6 \pm 0.0$ & 0.6 \\
\hline NED $170^{\circ} \mathrm{C}$ WPD & $88 \pm 0.1$ & $2 \pm 1$ & $0.3 \pm 0.1$ & $5.5 \pm 0.3$ & 3.1 \\
\hline NED $190^{\circ} \mathrm{C}$ WPD & $89 \pm 2$ & $2 \pm 1.6$ & $0.0 \pm 0.0$ & $5.5 \pm 0.3$ & 5.0 \\
\hline NED $200^{\circ} \mathrm{C}$ WPD & $87 \pm 12$ & $1 \pm 0.3$ & $0.0 \pm 0.0$ & $6.0 \pm 0.0$ & 9.3 \\
\hline Acid 1\% WPD & $88 \pm 0.8$ & $3 \pm 1$ & $0.5 \pm 0.1$ & $5.6 \pm 0.4$ & 2.4 \\
\hline Acid $2 \%$ WPD & $88 \pm 0.0$ & $3 \pm 0.4$ & $0.3 \pm 0.0$ & $5.3 \pm 0.1$ & 1.7 \\
\hline Acid 3\% WPD & $84 \pm 2$ & $2 \pm 1$ & $0.2 \pm 0.1$ & $5.8 \pm 0.1$ & 2.1 \\
\hline Acid 4\% WPD & $86 \pm 0.0$ & $4 \pm 0.0$ & $0.2 \pm 0.0$ & $5.7 \pm 0.4$ & 2.6 \\
\hline Untreated WPB & $77 \pm 2$ & $7 \pm 3$ & $2 \pm 0.2$ & $5.5 \pm 0.5$ & - \\
\hline Untreated WPD & $89 \pm 0.4$ & $3 \pm 0.4$ & $1 \pm 0.1$ & $5.6 \pm 0.2$ & - \\
\hline
\end{tabular}

The TS and VS contents of the samples used in the experiments are presented Table 2. The TS content of untreated banknote wastepaper varied between $915 \mathrm{~g} / \mathrm{kg}$ (WPB) and $956 \mathrm{~g} / \mathrm{kg}$ (WPD). For the remaining samples, the amount of dry matter differed from $918 \mathrm{~g} / \mathrm{kg}$ and $970 \mathrm{~g} / \mathrm{kg}$. The amount of VS for untreated WPB was $955 \mathrm{~g} / \mathrm{kgTS}$ and for untreated WPD $970 \mathrm{~g} / \mathrm{kgTS}$. The VS content was the lowest for WPB samples that were 
pretreated with acid 3\% (903 g/ $\mathrm{kgTS})$, and highest for WPD samples that were pretreated with NED $200{ }^{\circ} \mathrm{C}(979 \mathrm{~g} / \mathrm{kgTS})$.

Table 2. Total Solids and volatile solids content.

\begin{tabular}{|c|c|c|}
\hline Substrate & TS (g/kg) & VS (g/KgTS) \\
\hline $\mathrm{NED} 150^{\circ} \mathrm{C} \mathrm{WPB}$ & $960 \pm 5$ & $963 \pm 9$ \\
\hline NED $170{ }^{\circ} \mathrm{C} W P B$ & $957 \pm 9$ & $944 \pm 13$ \\
\hline NED $190^{\circ} \mathrm{C}$ WPB & $934 \pm 11$ & $945 \pm 1$ \\
\hline NED $200^{\circ} \mathrm{C}$ WPB & $958 \pm 6$ & $940 \pm 3$ \\
\hline Acid 1\% WPB & $947 \pm 8$ & $956 \pm 7$ \\
\hline Acid $2 \%$ WPB & $934 \pm 4$ & $930 \pm 3$ \\
\hline Acid 3\% WPB & $929 \pm 7$ & $903 \pm 6$ \\
\hline Acid $4 \%$ WPB & $970 \pm 1$ & $917 \pm 8$ \\
\hline NED $150^{\circ} \mathrm{C}$ WPD & $959 \pm 14$ & $966 \pm 2$ \\
\hline NED $170^{\circ} \mathrm{C}$ WPD & $954 \pm 0$ & $971 \pm 2$ \\
\hline NED $190^{\circ} \mathrm{C}$ WPD & $962 \pm 6$ & $973 \pm 0$ \\
\hline NED $200^{\circ} \mathrm{C}$ WPD & $961 \pm 0$ & $979 \pm 0$ \\
\hline Acid 1\% WPD & $953 \pm 6$ & $972 \pm 3$ \\
\hline Acid 2\% WPD & $945 \pm 2$ & $950 \pm 1$ \\
\hline Acid 3\% WPD & $918 \pm 5$ & $937 \pm 0$ \\
\hline Acid 4\% WPD & $952 \pm 1$ & $916 \pm 0$ \\
\hline Untreated WPB & $915 \pm 7$ & $955 \pm 16$ \\
\hline Untreated WPD & $953 \pm 3$ & $970 \pm 0$ \\
\hline
\end{tabular}

\subsection{Glucose Content from Pretreatment and Ethanol Content after Fermentation}

The increase in temperature used for the NED pretreatment of WPB resulted in a more efficient cellulose conversion to glucose as its concentration raised from $5.5 \pm 0.71 \mathrm{~g} / \mathrm{L}$ at $150{ }^{\circ} \mathrm{C}$ to $9.4 \pm 0.44 \mathrm{~g} / \mathrm{L}$ at $200{ }^{\circ} \mathrm{C}$ (Figure 2). The same trend was not observed for WPD as different temperatures used for the NED pretreatment did not result in statistically different $(p>0.05)$ glucose concentrations (Table A2, Appendix A). The use of NED pretreatment in WPD resulted in the highest glucose concentration of all studies $(13 \pm 0.19 \mathrm{~g} / \mathrm{L})$. The glucose yield of acid pretreated WPB showed a correlation with the acid concentration. The acid concentration of 2 and $3 \%$ resulted in $9.6 \pm 0.18$ and $9.8 \pm 0.61 \mathrm{~g} / \mathrm{L}$ of glucose, respectively. These concentrations were not different statistically and probably represent the range of optimum acid concentration for WPB pretreatment, as the performances of pretreatment using 1 and $4 \%$ of acid were inferior. The acid concentration on WPD pretreatment resulted in no significant statistical difference between the glucose concentrations obtained when using 1,2 , and $4 \%$ of acid ( $10.6 \mathrm{~g} / \mathrm{L}$ of glucose on average). Unexpectedly, the pretreatment with $3 \%$ of acid pretreatment in WPD resulted in a lower glucose concentration $(8.8 \pm 0.60 \mathrm{~g} / \mathrm{L})$.

The glucose-containing liquid phases from the different pretreatments of WPB and WPD were used as a substrate for bioethanol production using S. cerevisiae (Figure 3). As expected, the ethanol concentration reflected the initial glucose concentration. The highest ethanol concentration was obtained from the fermentation using WPD pretreated with NED $(6.4 \pm 0.72 \mathrm{~g} / \mathrm{L})$, however there was no statistical difference amongst the different temperatures used (Table A3, Appendix A). The ethanol yield from glucose was also the highest, $0.5 \mathrm{~g}$ ethanol/g glucose ( $98 \%$ of theoretical yield). The second highest ethanol concentration and yield were also from WPD using acid pretreatment, $4.9 \pm 0.20 \mathrm{~g} / \mathrm{L}$ and $0.46 \mathrm{~g}$ ethanol $/ \mathrm{g}$ glucose $(90 \%$ of the theoretical yield). The best results with WPB were when using pretreatments with $2 \%$ of acid and NED at $200{ }^{\circ} \mathrm{C}$, both about $4 \mathrm{~g} / \mathrm{L}$ of ethanol and $0.43 \mathrm{~g}$ ethanol/g glucose ( $84 \%$ of the theoretical yield). 


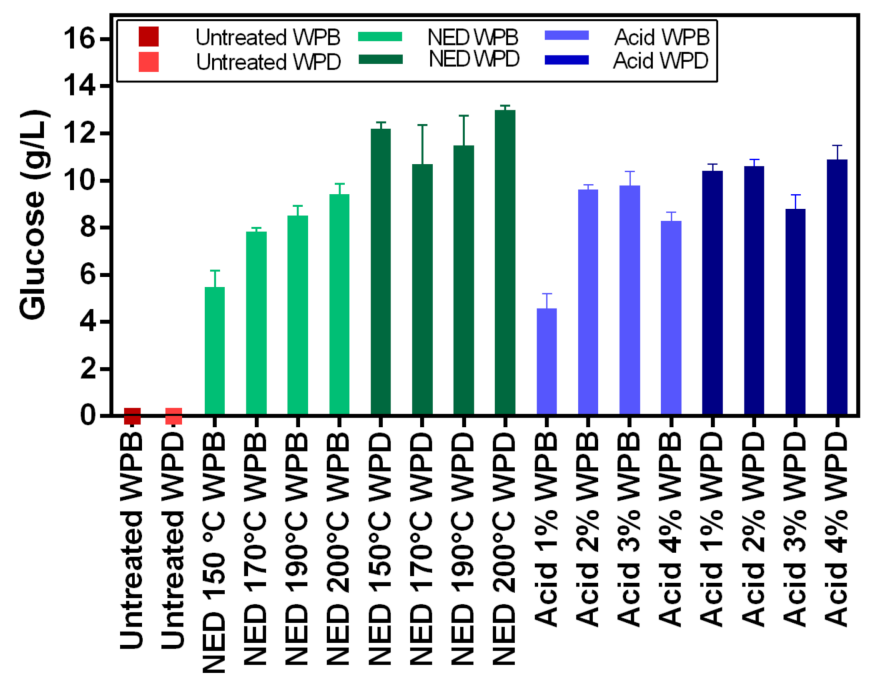

Figure 2. Glucose concentration for hydrolyzed WPB and WPD samples that were pretreated with NED at $150{ }^{\circ} \mathrm{C}, 170{ }^{\circ} \mathrm{C}, 190{ }^{\circ} \mathrm{C}$, and $200{ }^{\circ} \mathrm{C}$, and with acid $1 \%, 2 \%, 3 \%$, and $4 \%$.

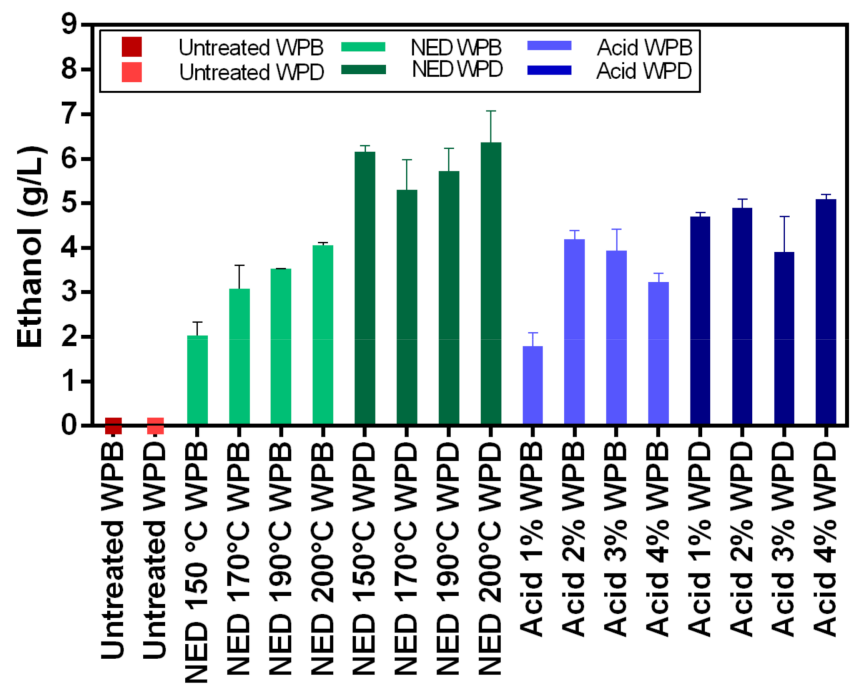

Figure 3. The concentrations of ethanol after the fermentation stage for WPB and WPD samples that were pretreated with NED at $150{ }^{\circ} \mathrm{C}, 170{ }^{\circ} \mathrm{C}, 190^{\circ} \mathrm{C}$, and $200^{\circ} \mathrm{C}$ and with acid $1 \%, 2 \%, 3 \%$, and $4 \%$.

When it comes to the hydrolysis efficiency (Table 3), the results show relatively low values (between $5-15 \%$ ). This can be attributed to the nature of the banknote paper. The cotton structure (main component of banknote paper) is highly crystalline in nature and thus, recalcitrant to enzymatic hydrolysis. Both pretreatments have only limited effect on reducing crystallinity of the cellulose in the paper. The highest hydrolysis efficiencies were obtained with acid pretreatment of WPB samples however, this is due to the fact that in the deinking process some of the amorphous cellulose is lost. On the other hand, the fermentation efficiencies of these same samples are lower due to the presence of inhibitory compounds originating from the ink. Fermentation efficiency varies between $73 \%$ and $99 \%$ and is clearly higher for deinked samples. 
Table 3. Hydrolysis and fermentation efficiency.

\begin{tabular}{|c|c|c|}
\hline & Hydrolysis Efficiency & Fermentation Efficiency \\
\hline NED $150^{\circ} \mathrm{C}$ WPB & 6 & 73 \\
\hline NED $170{ }^{\circ} \mathrm{C} W P B$ & 8 & 77 \\
\hline NED $190{ }^{\circ} \mathrm{C} W P B$ & 10 & 81 \\
\hline NED $200{ }^{\circ} \mathrm{C}$ WPB & 10 & 84 \\
\hline Acid 1\% WPB & 13 & 77 \\
\hline Acid 2\% WPB & 12 & 85 \\
\hline Acid 3\% WPB & 15 & 79 \\
\hline Acid 4\% WPB & 15 & 76 \\
\hline NED $150{ }^{\circ} \mathrm{C}$ WPD & 5 & 99 \\
\hline NED $170{ }^{\circ} \mathrm{C}$ WPD & 10 & 97 \\
\hline NED $190^{\circ} \mathrm{C}$ WPD & 10 & 98 \\
\hline NED $200{ }^{\circ} \mathrm{C}$ WPD & 9 & 96 \\
\hline Acid 1\% WPD & 11 & 89 \\
\hline Acid 2\% WPD & 11 & 91 \\
\hline Acid 3\% WPD & 9 & 87 \\
\hline Acid 4\% WPD & 11 & 92 \\
\hline
\end{tabular}

\subsection{Potential of Waste Banknote Paper for Biomethane Production}

\subsubsection{Methane Yields}

In Figure 4 the biomethane potentials for untreated sample and for WPB samples that were pretreated with NED at $150{ }^{\circ} \mathrm{C}, 170^{\circ} \mathrm{C}, 190^{\circ} \mathrm{C}$, and $200^{\circ} \mathrm{C}$ are presented. Samples that were pretreated at $150^{\circ} \mathrm{C}$ had the highest biomethane yields $(266 \mathrm{~L} / \mathrm{kg}$ TS), followed by those that were pretreated at $190^{\circ} \mathrm{C}(261 \mathrm{~L} / \mathrm{kg} \mathrm{TS})$, untreated material $(238 \mathrm{~L} / \mathrm{kg} \mathrm{TS})$, $200{ }^{\circ} \mathrm{C}(208 \mathrm{~L} / \mathrm{kg} \mathrm{TS})$, and $170{ }^{\circ} \mathrm{C}(202 \mathrm{~L} / \mathrm{kg} \mathrm{TS})$.

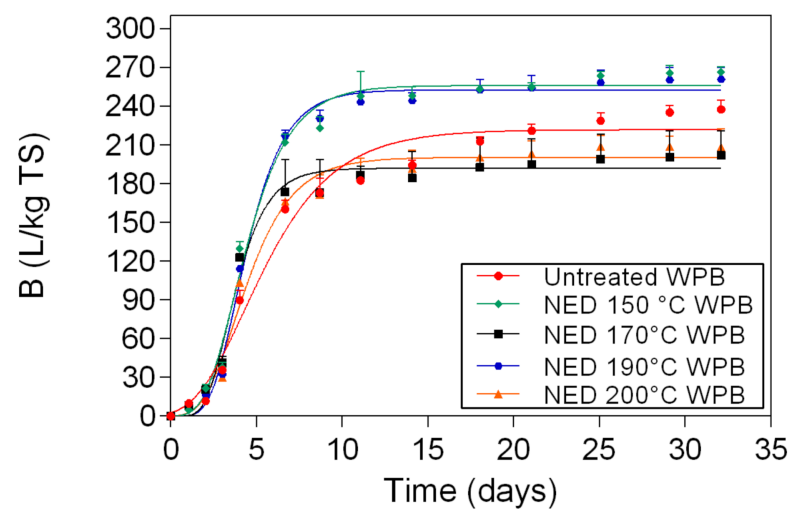

Figure 4. Biomethane potential measurement results and respective fitting curves for untreated samples and for WPB samples that were pretreated with NED at $150{ }^{\circ} \mathrm{C}, 170{ }^{\circ} \mathrm{C}, 190^{\circ} \mathrm{C}$, and $200^{\circ} \mathrm{C}$.

The biomethane results of untreated sample and WPB samples that were pretreated with acid at $1 \%, 2 \%, 3 \%$, and $4 \%$ are shown in Figure 5 . The biomethane yield varied between $150 \mathrm{~L} / \mathrm{kg}$ TS (samples that were pretreated with acid $2 \%$ ) and $263 \mathrm{~L} / \mathrm{kg}$ TS (samples that were pretreated with acid $4 \%$ ). 


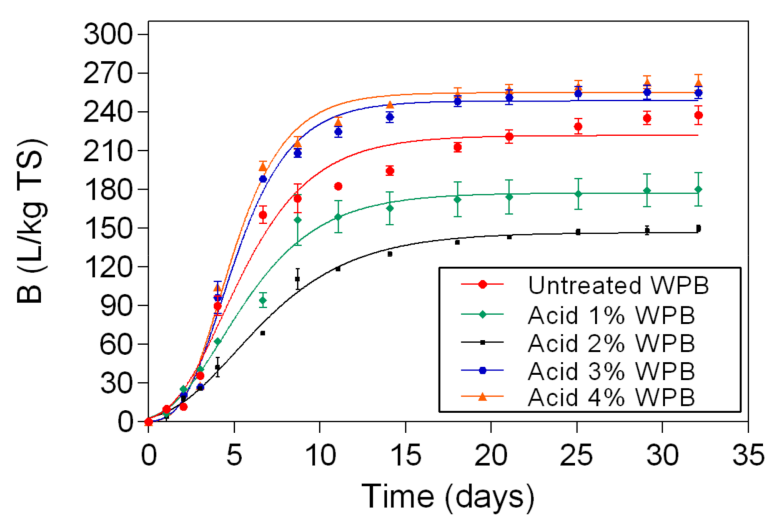

Figure 5. Biomethane potential measurement results and respective fitting curves for untreated samples and for WPB samples that were pretreated with acid at $1 \%, 2 \%, 3 \%$, and $4 \%$.

The biomethane potential of untreated WPD and of samples that were pretreated with NED (WPD) is illustrated in Figure 6. Untreated WPD had the lowest biomethane yields (202 L/kg TS), while samples that were pretreated with NED at $200{ }^{\circ} \mathrm{C}$ (WPD) had the highest biomethane yields $(291 \mathrm{~L} / \mathrm{kg}$ TS). The biomethane yields of samples that were pretreated with NED $170{ }^{\circ} \mathrm{C}$ (WPD) was $217 \mathrm{~L} / \mathrm{kg}$ TS, followed by samples that were pretreated with NED $150{ }^{\circ} \mathrm{C}$ (WPD) $\left(232 \mathrm{~L} / \mathrm{kg}\right.$ TS), and NED $190^{\circ} \mathrm{C}$ (WPD) $(236 \mathrm{~L} / \mathrm{kg} \mathrm{TS})$. Statistically significant differences were found between untreated material and samples that were pretreated with NED at different temperatures (Table A4, Appendix A).

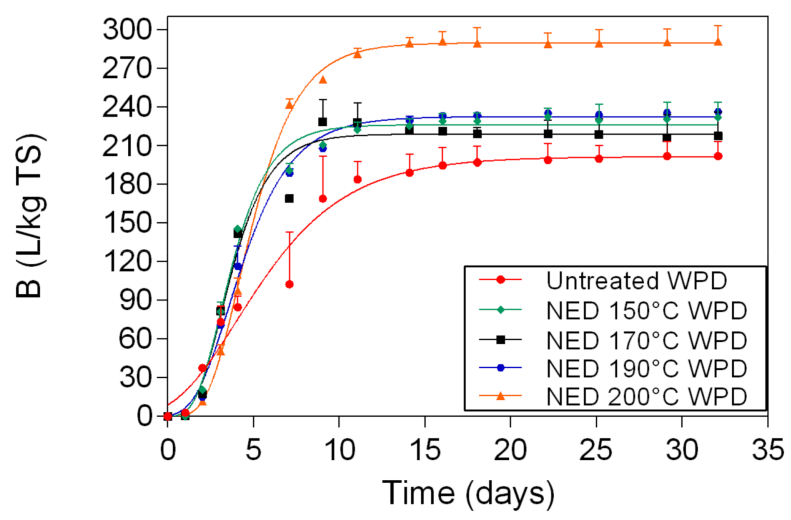

Figure 6. Biomethane potential measurement results and respective fitting curves for untreated samples and for WPD samples that were pretreated with NED at $150{ }^{\circ} \mathrm{C}, 170^{\circ} \mathrm{C}, 190^{\circ} \mathrm{C}$, and $200{ }^{\circ} \mathrm{C}$.

The biomethane potential of untreated WPD and samples that were pretreated with acid at $1 \%, 2 \%, 3 \%$, and $4 \%$ (WPD) is reported in Figure 7 . The biomethane yield of WPD was $202 \mathrm{~L} / \mathrm{kg}$ TS, followed by samples that were pretreated with $1 \%$ acid WPD $(218 \mathrm{~L} / \mathrm{kg}$ TS), $4 \%$ acid WPD (260 L/kg TS), 2\% acid WPD (289 L/kg TS), and 3\% acid WPD (299 L/kg TS). Statistically significant differences were found between untreated WPD and samples pretreated with acid (Table A4, Appendix A). 


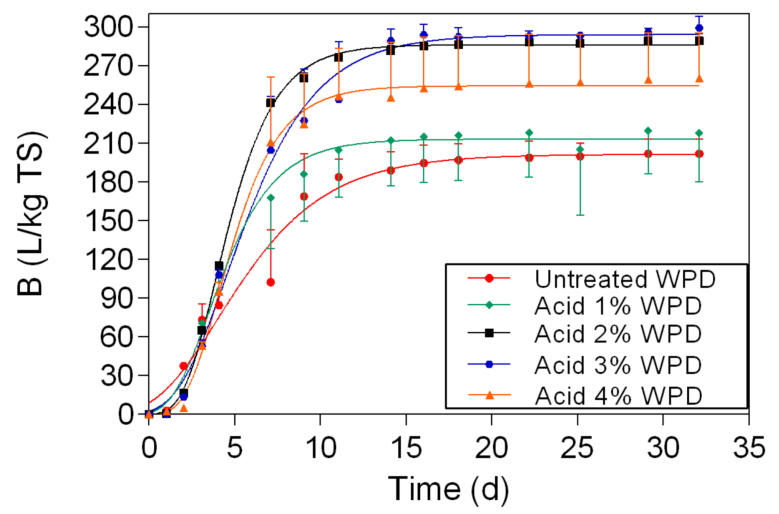

Figure 7. Biomethane potential measurement results and respective fitting curves for untreated samples and for WPD samples that were pretreated with acid at $1 \%, 2 \%, 3 \%$, and $4 \%$.

The maximum methane yield for WPB samples that were pretreated with NED at $150{ }^{\circ} \mathrm{C}, 170{ }^{\circ} \mathrm{C}, 190{ }^{\circ} \mathrm{C}$, and $200^{\circ} \mathrm{C}$ and with acid at $1 \%, 2 \%, 3 \%$, and $4 \%$ shown in Figure 8 . The maximum methane yield of untreated WPB was $222 \mathrm{~L} / \mathrm{kg}$ TS. For samples (WPB) that were pretreated with NED, the maximum methane yields varied between $192 \mathrm{~L} / \mathrm{kg}$ TS (samples that were pretreated with NED at $170{ }^{\circ} \mathrm{C}$ ) and $256 \mathrm{~L} / \mathrm{kg}$ TS (samples that were pretreated with NED at $150{ }^{\circ} \mathrm{C}$ ). For samples (WPB) that were pretreated with acid the maximum methane yield was lower at $2 \%(136 \mathrm{~L} / \mathrm{kg} \mathrm{TS})$ and higher at $4 \%(255 \mathrm{~L} / \mathrm{kg}$ TS). The maximum methane yield of untreated WPD was $201 \mathrm{~L} / \mathrm{kg}$ TS. For samples (WPD) that were pretreated with NED, the maximum methane yields ranged between $219 \mathrm{~L} / \mathrm{kg}$ TS (NED $170{ }^{\circ} \mathrm{C} \mathrm{WPD}$ ) and $290 \mathrm{~L} / \mathrm{kg}$ TS (NED $200^{\circ} \mathrm{C} \mathrm{WPD),} \mathrm{while} \mathrm{for} \mathrm{samples} \mathrm{(WPD)} \mathrm{that}$ were pretreated with acid it ranged between $147 \mathrm{~L} / \mathrm{kg}$ TS (acid 2\% WPD) and $294 \mathrm{~L} / \mathrm{kg}$ TS (acid 3\% WPD). Statistically significant differences were found between NED $200{ }^{\circ} \mathrm{C}$ WPD vs. NED $200{ }^{\circ} \mathrm{C}$ WPB and Acid 2\% WPD vs. Acid 2\% WPB (Table A4, Appendix A).

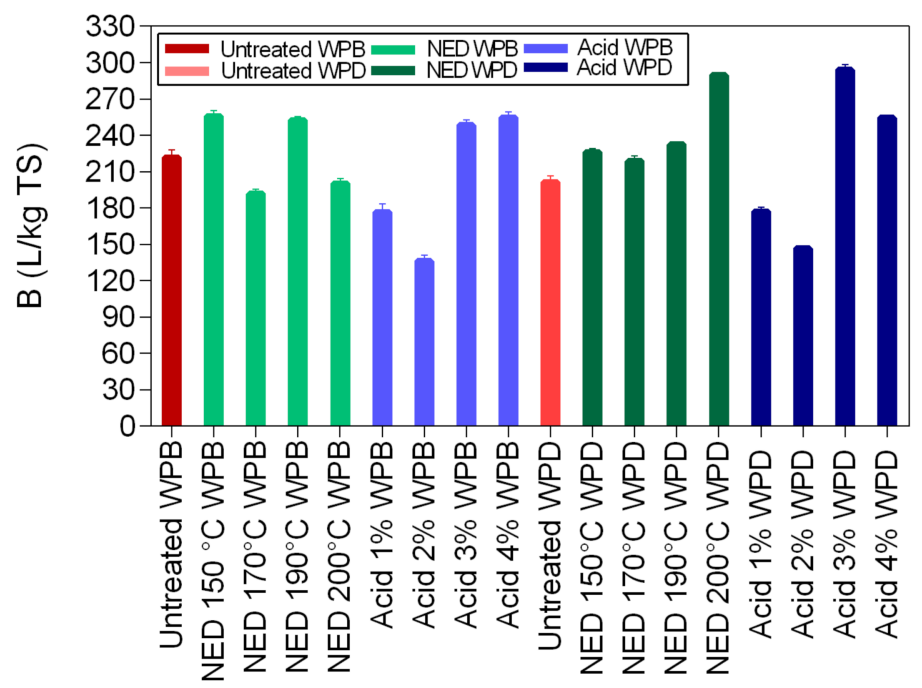

Figure 8. Maximum methane yields $\left(\mathrm{B}_{\max }\right)$ of the fitting curves for WPB and WPD samples that were pretreated with NED at $150{ }^{\circ} \mathrm{C}, 170{ }^{\circ} \mathrm{C}, 190^{\circ} \mathrm{C}$, and $200{ }^{\circ} \mathrm{C}$ and with acid at $1 \%, 2 \%, 3 \%$, and $4 \%$.

\subsubsection{Digestion Time}

The digestion time to reach $85 \%\left(\mathrm{~B}_{85}\right)$ and $95 \%\left(\mathrm{~B}_{95}\right)$ of maximum biomethane potential and the Gompertz growth parameters for WPB and WPD samples that were pretreated with NED at $150{ }^{\circ} \mathrm{C}, 170{ }^{\circ} \mathrm{C}, 190{ }^{\circ} \mathrm{C}$, and $200{ }^{\circ} \mathrm{C}$ and with acid at $1 \%, 2 \%, 3 \%$, and $4 \%$ are shown in Table 4. Untreated WPB needed 14 days (201 L/ $\mathrm{kg}$ TS) to achieve B85 and 21 days $(225 \mathrm{~L} / \mathrm{kg}$ TS) to reach B95, while untreated WPD required 7.4 days (172 L/ $\mathrm{kg}$ TS) 
to achieve B85 and 11 days (193 L/ kg TS) to reach B95. Overall, WPB samples that were pretreated with $1 \%$ acid and WPB samples that were pretreated with NED $150{ }^{\circ} \mathrm{C}$ and NED $170{ }^{\circ} \mathrm{C}$ require less time to achieve B85. WPD samples that were pretreated with $3 \%$ acid and WPB samples that were pretreated with $3 \%$ acid and $4 \%$ acid need more time to reach B85. A similar trend is followed for B95.

Table 4. Digestion time to achieve $85 \%\left(\mathrm{~B}_{85}\right)$ and $95 \%\left(\mathrm{~B}_{95}\right)$ of maximum biomethane potential and Gompertz growth parameters for WPB and WPD that were pretreated with NED at $150{ }^{\circ} \mathrm{C}, 170{ }^{\circ} \mathrm{C}, 190{ }^{\circ} \mathrm{C}$, and $200{ }^{\circ} \mathrm{C}$ and with acid at $1 \%$, $2 \%, 3 \%$, and $4 \%$.

\begin{tabular}{cccccccc}
\hline & \multicolumn{2}{c}{$\mathbf{B}_{\mathbf{8 5}}$} & \multicolumn{2}{c}{$\mathbf{B}_{\mathbf{9 5}}$} & & \multicolumn{2}{c}{ Gompertz Growth } \\
\hline & L/kg TS & Days & L/kg TS & Days & $\mathbf{Y}_{\mathbf{M}}$ & \multicolumn{1}{c}{$\mathbf{Y}_{\mathbf{0}}$} & K \\
\hline NED 150 ${ }^{\circ} \mathrm{C}$ WPB & 231 & 11 & 258 & 17 & $256 \pm 4$ & $0.06 \pm 0.1$ & $0.6 \pm 0.07$ \\
NED 170 ${ }^{\circ}$ WPB & 173 & 10 & 193 & 16 & $192 \pm 4$ & $0.0002 \pm 0.001$ & $0.8 \pm 0.1$ \\
NED 190 ${ }^{\circ}$ WPB & 228 & 11 & 255 & 17 & $253 \pm 3$ & $0.001 \pm 0.003$ & $0.6 \pm 0.06$ \\
NED 200 ${ }^{\circ}$ WPB & 181 & 12 & 203 & 18 & $200 \pm 4$ & $0.09 \pm 0.2$ & $0.5 \pm 0.08$ \\
\hline Acid 1\% WPB & 154 & 7.7 & 172 & 12 & $177 \pm 3$ & $3 \pm 2$ & $0.3 \pm 0.03$ \\
Acid 2\% WPB & 126 & 11 & 140 & 17 & $147 \pm 3$ & $3 \pm 1$ & $0.3 \pm 0.02$ \\
Acid 3\% WPB & 224 & 13 & 251 & 19 & $249 \pm 4$ & $0.3 \pm 0.4$ & $0.4 \pm 0.04$ \\
Acid 4\% WPB & 230 & 13 & 257 & 19 & $255 \pm 4$ & $0.2 \pm 0.3$ & $0.5 \pm 0.05$ \\
\hline NED 150 ${ }^{\circ}$ C WPD & 202 & 9.7 & 226 & 15 & $226 \pm 3$ & $0.08 \pm 0.1$ & $0.7 \pm 0.07$ \\
NED 170 C WPD & 195 & 8.0 & 218 & 12 & $219 \pm 4$ & $0.08 \pm 0.2$ & $0.6 \pm 0.1$ \\
NED 190 C WPD & 207 & 11 & 232 & 17 & $232 \pm 2$ & $0.6 \pm 0.5$ & $0.5 \pm 0.04$ \\
NED 200 ${ }^{\circ}$ C WPD & 260 & 12 & 291 & 18 & $290 \pm 1$ & $0.02 \pm 0.01$ & $0.5 \pm 0.02$ \\
\hline Acid 1\% WPD & 190 & 11 & 212 & 17 & $213 \pm 3$ & $1 \pm 1$ & $0.5 \pm 0.05$ \\
Acid 2\% WPD & 256 & 12 & 286 & 17 & $286 \pm 1$ & $0.1 \pm 0.06$ & $0.5 \pm 0.02$ \\
Acid 3\% WPD & 264 & 14 & 295 & 21 & $294 \pm 4$ & $2 \pm 1$ & $0.3 \pm 0.03$ \\
Acid 4\% WPD & 229 & 12 & 256 & 18 & $254 \pm 2$ & $0.07 \pm 0.07$ & $0.5 \pm 0.03$ \\
\hline Untreated WPB & 201 & 14 & 225 & 21 & $222 \pm 6$ & $3 \pm 2$ & $0.3 \pm 0$ \\
\hline Untreated WPD & 172 & 7.4 & 193 & 11 & $201 \pm 5$ & $9 \pm 4$ & $0.3 \pm 0.04$ \\
\hline
\end{tabular}

Untreated WPB needed 14 days $\left(201 \mathrm{~L} / \mathrm{kg}\right.$ TS) to achieve $\mathrm{B}_{85}$ and 21 days $(225 \mathrm{~L} / \mathrm{kg}$ TS) to reach $\mathrm{B}_{95}$, while untreated WPD required 7.4 days $\left(172 \mathrm{~L} / \mathrm{kg}\right.$ TS) to achieve $\mathrm{B}_{85}$ and 11 days $\left(193 \mathrm{~L} / \mathrm{kg}\right.$ TS) to reach $\mathrm{B}_{95}$. Overall, WPB samples that were pretreated with $1 \%$ acid and WPB samples that were pretreated with NED $150{ }^{\circ} \mathrm{C}$ and NED $170{ }^{\circ} \mathrm{C}$ require less time to achieve $\mathrm{B}_{85}$. WPD samples that were pretreated with $3 \%$ acid and WPB samples that were pretreated with $3 \%$ acid and $4 \%$ acid need more time to reach $\mathrm{B}_{85}$. A similar trend is followed for $\mathrm{B}_{95}$.

\section{Discussion}

\subsection{Chemical Composition}

The cellulose content reported in this study was $6 \%$ to $18 \%$ lower than the values reported in the literature [ 314 however, the overall percentage of cellulose was still very high $(>77 \%)$. The high percentage of cellulose that was found in the waste banknote paper is due to its composition. Waste banknote paper has high amounts of cotton, which has mainly cellulose on its composition. The results obtained in this study were also compared with the chemical composition of cotton crops reported by Rocha-Meneses et al. [15]. The authors described the content of cellulose and hemicellulose present in cotton as $80-95 \%$ and $5-20 \%$, respectively, which is in line with the results found in our study. These results are favorable for bioethanol and biogas production since research has shown that high amounts of cellulose contribute to high yields of bioethanol and biomethane. The hemicellulose and lignin contents are within the range of values reported in the literature [31]. Moreover, low lignin content is advantageous since the amount of energy 
that is required to break down the chemical bonds between hemicellulose and lignin and to make cellulose accessible for the enzymatic hydrolysis is low [20,32].

The amounts of TS and VS are fundamental when it comes to biogas production. High amounts of TS specify the amount of substrate that is accessible for the anaerobic digestion process, while high amounts of VS refer to the amount of substrate that can be transformed into biomethane. When compared with similar subtracts, higher amounts of VS lead to higher amounts of biogas [32,33].

\subsection{Glucose Content after Hydrolysis and Ethanol Content after Fermentation}

The use of WPD resulted in higher glucose and ethanol concentrations and yields when compared to WPB regardless of the pretreatment. A previous study also showed that the deinking process improved ethanol production of the pretreated waste banknote [26]. In this present work, when fermenting the NED-pretreated WPD, we were able to achieve $6.36 \mathrm{~g} / \mathrm{L}$ of ethanol and $98 \%$ of the theoretical ethanol yield from glucose $(0.50 \mathrm{~g}$ ethanol $/ \mathrm{g}$ glucose). Although the ethanol concentration achieved is lower than the one obtained by Rocha-Meneses et al. [32] when using NED pretreatment to Napier grass as a fermentation substrate $(10.3 \mathrm{~g} / \mathrm{L})$, a lower bioethanol yield $(90 \%$ of the theoretical yield) was reported by the authors, probably by the presence of microbial growth inhibitors. No microbial inhibition effect was observed when using pretreated WPD as a fermentation substrate. Jeihanipour and Taherzadeha (2009) [34] reported a yield of $0.48 \mathrm{~g}$ ethanol/g textile from alkali pretreated cotton linter and waste jeans as a substrate for $S$. cerevisiae during a simultaneous saccharification and fermentation process (SSF). The yield reported by Jeihanipour and Taherzadeha (2009) [34] is higher than the one obtained in the present work (0.21 $\mathrm{g}$ ethanol/g waste banknote), but this yield can possibly be enhanced by optimizing the enzymatic hydrolysis step increasing glucose content, and, therefore, the ethanol production, as shown previously by Aghmashhadi et al. (2020) [26], widening the potential of this waste biomass utilization.

\subsection{Potential of Waste Banknote Paper for Biomethane Production}

From Figure 4 it is evident that samples of WPB that were pretreated with NED at $150{ }^{\circ} \mathrm{C}$ and $190^{\circ} \mathrm{C}$ produce $12-13 \%$ more biomethane than untreated WPB, while samples that were pretreated at $170{ }^{\circ} \mathrm{C}$ and $200{ }^{\circ} \mathrm{C}$ have biomethane yields $9-15 \%$ lower than untreated WPB. At the moment, the mechanism behind these differences is not clear. As there is clearer trend in WPD, the hectic results of WPB might be due to the presence of ink and its interactions with the other compounds that are produced during the pretreatment at high temperature. Moreover, it might be due to the different amounts of ink present in different samples of WPB. Not all of the banknote is uniformly covered with the same kind of ink. Furthermore, these pretreatment methods are effective only under certain temperatures, which could require further studies in order to investigate the optimum pretreatment temperature for the anaerobic digestion process [35,36]. If the experiments are performed outside the optimum pretreatment temperatures it can lead to the production of inhibitory compounds and a decrease in the substrate biodegradability [37,38].

As it can be seen from Figure 5 only pretreatment with $3 \%$ and $4 \%$ acid increased biomethane production compared to untreated sample for WPB. Samples that were pretreated with high acid concentrations showed biomethane content $10-12 \%$ higher than untreated banknote paper. Similar results were reported by Sarto, Hildayati and Syaichurrozi (2019) [39]. On the other hand, lower concentrations of acid in the pretreatment seems to inhibit the biomethane production. This can be due to the composition of the samples. As the samples still have ink in their composition, probably harsher pretreatment methods are required to disrupt the structure of the banknote paper and access the cellulose, as well as longer retention times, since the degradation rate will be slower. Moreover, the utilization of acid to adjust the $\mathrm{pH}$ can have led to excessive sugar degradation and the production of inhibitory compounds [40]. A study reported by Venturin et al. [41] showed that $\mathrm{H}_{2} \mathrm{SO}_{4}$ pretreatment inhibited biogas production. In order to ascertain the 
exact mechanism, further studies should be performed, with different retention times in the acid pretreatment, and different reagents of $\mathrm{pH}$ adjustment.

The biomethane yields of samples that were pretreated with NED (WPD) (Figure 6) were $8-44 \%$ higher than the biomethane yields of untreated material. As it is shown in Figure 7, the biomethane content of samples that where pretreated with acid (WPD) was 8-48\% higher than the biomethane content of untreated banknote paper. Overall, the biomethane yields of deinking samples (NED WPD and acid WPD) were highly improved, when compared with blank samples (NED WPB and acid WPB). For samples that were pretreated with NED, the biomethane yields of WPD were 8-35\% higher than the biomethane yields of WPB. For samples that were pretreated with acid, the biomethane yields of WPD were 17-93\% higher than the biomethane yields of WPB. These differences between WPB and WPD samples can be explained by the deinking process. The ink removal uses alkali as a solution. This means that deinking samples are subjected to two combined pretreatment methods alkali and NED. This can leave waste banknote paper with an increased amorphous structure, higher traits and quality, which will increase its biodegradability by the anaerobic microorganisms and as a result, increase biomethane yields.

As it is evident from Figure 8, samples that were pretreated with acid $2 \%$ WPB, acid $1 \% \mathrm{WPB}, \mathrm{NED} 170{ }^{\circ} \mathrm{C} \mathrm{WPB}, \mathrm{NED} 200{ }^{\circ} \mathrm{C} \mathrm{WPB}$, had the lowest biomethane yields (between $136 \mathrm{~L} / \mathrm{kg}$ TS and $200 \mathrm{~L} / \mathrm{kg} \mathrm{TS}$ ), while samples that were pretreated with acid $4 \% \mathrm{WPD}$, NED $200{ }^{\circ} \mathrm{C}$ WPD, and acid 3\% WPD had the highest biomethane yields (between $254 \mathrm{~mol} / \mathrm{kg}$ TS and $294 \mathrm{~mol} / \mathrm{kg}$ TS). These results can be explained by the deinking process, by the effect of high acid concentrations, and by the effect of high pretreatment temperatures. Research has shown that the presence on ink in waste paper inhibits the enzymatic hydrolysis, and reduces the amount of sugars available for the fermentation stage, which results in inefficient bioethanol production [42]. Therefore, as expected, samples without ink resulted in better yields than samples with ink. On the other hand, high acid concentrations reduce the crystalline structure of cellulose more efficiently, making it more accessible for the enzymatic hydrolysis, which will lead to higher bioethanol and biogas yields $[39,43,44]$. The temperature also plays a role in biomethane yields. Research has shown that cellulose solubilization increases proportionally with the increment of the pretreatment temperature $[39,45]$.

The differences in the digestion time between WPD and WPB can be explained by the presence of ink. Research has shown that the presence of ink can inhibit biorefinery processes [26].

These results are particularly important when it comes to the reduction of environmental impacts caused by the incineration or landfilling of waste banknote paper. At the moment, these are the most common handling options that are being applied to waste banknote paper. However, incineration and landfilling are a source of environmental pollution, contaminating the air, soil and water. Therefore, the Central Bank of Iran has decided to take action and reduce its environmental footprint caused by waste banknote paper and shift to waste management solutions that are more environmentally friendly. Therefore, biogas and bioethanol production are proposed as alternative handling options for these residues since it is known that they have a lower footprint when compared to incineration or landfilling [46]. Further research should be performed in order to make this solution competitive and to quantify the energy output from biogas, bioethanol, incineration and landfilling of waste banknote paper.

\section{Conclusions}

In this study, two different pretreatment methods (chemical and physio-chemical) were used to investigate the potential of waste banknote paper with and without ink for bioethanol and biomethane production. The results of this study show that glucose and ethanol concentrations are higher in WPD samples than for WPB. The glucose yields varied between $4.57 \mathrm{~g} / \mathrm{L}\left(1 \%\right.$ acid WPB) and $12.98 \mathrm{~g} / \mathrm{L}\left(\mathrm{NED} 200^{\circ} \mathrm{C}\right.$ WPD), while ethanol yields varied between $1.8 \mathrm{~g} / \mathrm{L}\left(1 \%\right.$ Acid WPB) and $6.36 \mathrm{~g} / \mathrm{L}$ (NED $200{ }^{\circ} \mathrm{C}$ WPD). For WPB 
samples, the highest biomethane yields were reported in samples that were pretreated with NED $150{ }^{\circ} \mathrm{C}(266 \mathrm{~L} / \mathrm{kg} \mathrm{TS})$ and $4 \%$ acid $(263 \mathrm{~L} / \mathrm{Kg} \mathrm{TS})$. For WPD samples, samples that were pretreated with $3 \%$ acid $\left(299 \mathrm{~L} / \mathrm{Kg}\right.$ TS) and NED $200{ }^{\circ} \mathrm{C}(292 \mathrm{~L} / \mathrm{Kg}$ TS) pretreatments insured the highest biomethane production. In general, the biomethane potential of WPD samples was higher than that of similarly pretreated WPB samples. NED pretreatment method gives higher glucose, ethanol, and biomethane yields than samples that were pretreated with sulfuric acid. The deinking process, the acid concentration, and the pretreatment temperature all influence glucose, bioethanol, and biomethane yields. More research should be done to find the most efficient ways to increase glucose, bioethanol, and biomethane yields.

Author Contributions: Conceptualization, O.Y.A., L.R.-M., and T.K.; methodology, O.Y.A., L.R.-M. and N.B.; software, L.R.-M.; validation, O.Y.A., L.R.-M. and N.B., and T.K.; formal analysis, L.R.-M.; investigation, O.Y.A., L.R.-M. and N.B.; resources, T.K.; data curation, L.R.-M. and N.B.; writingoriginal draft preparation, O.Y.A., L.R.-M., N.B., K.O. and T.K.; writing-review and editing, L.R.-M., N.B., K.O. and T.K.; visualization, L.R.-M.; supervision, L.R.-M., G.A., E.R.G., M.Z. and T.K.; project administration, T.K.; funding acquisition, T.K. All authors have read and agreed to the published version of the manuscript.

Funding: We gratefully acknowledge the financial support of the Doctoral School of Energy and Geotechnology III, supported by the European Union, European Regional Development Fund (Estonian University of Life Sciences ASTRA project "Value-chain based bio-economy"). The HPLC analyses were funded by European Union's Horizon 2020 research and innovation program under grant agreement No 668997 and the Estonian Research Council (grant PUT1488P).

Institutional Review Board Statement: Not applicable.

Informed Consent Statement: Not applicable.

Data Availability Statement: Not applicable.

Conflicts of Interest: The authors declare no conflict of interest.

Appendix A

Table A1. Two-way ANOVA, Tukey's multiple comparisons test, for cellulose content.

\begin{tabular}{|c|c|c|c|c|}
\hline Dunn's Multiple Comparisons Test & Mean Rank Diff. & Significant? & Summary & Adjusted $p$ Value \\
\hline Acid $3 \%$ WPB vs. NED $150{ }^{\circ} \mathrm{C}$ WPB & -29.58 & Yes & $* * * *$ & $<0.0001$ \\
\hline Acid $3 \%$ WPB vs. NED $170{ }^{\circ} \mathrm{C} W P B$ & -28.6 & Yes & $* * *$ & 0.0001 \\
\hline Acid 3\% WPB vs. NED $190{ }^{\circ} \mathrm{C}$ WPB & -22.89 & Yes & $* *$ & 0.0074 \\
\hline Acid $3 \%$ WPB vs. NED $200{ }^{\circ} \mathrm{C}$ WPB & -27.8 & Yes & $* * *$ & 0.0002 \\
\hline Acid $3 \%$ WPB vs. NED $150{ }^{\circ} \mathrm{C}$ WPD & -33.52 & Yes & $* * * *$ & $<0.0001$ \\
\hline Acid $3 \%$ WPB vs. NED $170{ }^{\circ} \mathrm{C}$ WPD & -32.84 & Yes & $* * * *$ & $<0.0001$ \\
\hline Acid 3\% WPB vs. NED $190^{\circ} \mathrm{C}$ WPD & -32.67 & Yes & $* * * *$ & $<0.0001$ \\
\hline Acid 3\% WPB vs. NED $200^{\circ} \mathrm{C}$ WPD & -32.33 & Yes & $* * * *$ & $<0.0001$ \\
\hline Acid 3\% WPB vs. Acid 1\% WPB & -29.52 & Yes & $* * * *$ & $<0.0001$ \\
\hline Acid $3 \%$ WPB vs. Acid $\%$ WPB & -27.38 & Yes & $* * *$ & 0.0003 \\
\hline Acid $4 \%$ WPB vs. Acid 3\% WPB & 23.46 & Yes & $* *$ & 0.0052 \\
\hline Acid 1\% WPD vs. Acid 3\% WPB & 33.26 & Yes & $* * * *$ & $<0.0001$ \\
\hline Acid $2 \%$ WPD vs. Acid 3\% WPB & 32.5 & Yes & $* * * *$ & $<0.0001$ \\
\hline Acid 3\% WPD vs. Acid 3\% WPB & 29.23 & Yes & $* * * *$ & $<0.0001$ \\
\hline Acid 4\% WPD vs. Acid 3\% WPB & 30.37 & Yes & $* * * *$ & $<0.0001$ \\
\hline Untreated WPB vs. Acid 3\% WPB & 22.15 & Yes & * & 0.0118 \\
\hline Untreated WPD vs. Acid 3\% WPB & 33.76 & Yes & $* * * *$ & $<0.0001$ \\
\hline
\end{tabular}

${ }^{*} p \leq 0.05,{ }^{* *} p \leq 0.01,{ }^{* * *} p \leq 0.001,{ }^{* * * *} p \leq 0.0001$.


Table A2. Two-way ANOVA, Tukey's multiple comparisons test, for glucose yields.

\begin{tabular}{|c|c|c|c|c|}
\hline Dunn's Multiple Comparisons Test & Mean Rank Diff. & Significant? & Summary & Adjusted $p$ Value \\
\hline NED $150{ }^{\circ} \mathrm{C}$ WPB vs. NED $170{ }^{\circ} \mathrm{C}$ WPB & -2.36 & Yes & $* * *$ & 0.0002 \\
\hline NED $150{ }^{\circ} \mathrm{C}$ WPB vs. NED $190{ }^{\circ} \mathrm{C}$ WPB & -3.02 & Yes & $* * * *$ & $<0.0001$ \\
\hline NED $150{ }^{\circ} \mathrm{C}$ WPB vs. NED $200{ }^{\circ} \mathrm{C}$ WPB & -3.95 & Yes & $* * * *$ & $<0.0001$ \\
\hline NED $150^{\circ} \mathrm{C}$ WPB vs. NED $150^{\circ} \mathrm{C}$ WPD & -6.72 & Yes & $* * * *$ & $<0.0001$ \\
\hline NED $150^{\circ} \mathrm{C}$ WPB vs. NED $170^{\circ} \mathrm{C}$ WPD & -5.21 & Yes & $* * * *$ & $<0.0001$ \\
\hline NED $150^{\circ} \mathrm{C}$ WPB vs. NED $190^{\circ} \mathrm{C}$ WPD & -6.02 & Yes & $* * * *$ & $<0.0001$ \\
\hline NED $150^{\circ} \mathrm{C}$ WPB vs. NED $200^{\circ} \mathrm{C}$ WPD & -7.5 & Yes & $* * * *$ & $<0.0001$ \\
\hline NED $150{ }^{\circ} \mathrm{C}$ WPB vs. Acid $2 \%$ WPB & -4.15 & Yes & $* * * *$ & $<0.0001$ \\
\hline NED $150{ }^{\circ} \mathrm{C}$ WPB vs. Acid $3 \%$ WPB & -4.3 & Yes & $* * * *$ & $<0.0001$ \\
\hline NED $150{ }^{\circ} \mathrm{C}$ WPB vs. Acid $4 \%$ WPB & -2.8 & Yes & $* * * *$ & $<0.0001$ \\
\hline NED $150{ }^{\circ} \mathrm{C}$ WPB vs. Acid $1 \%$ WPD & -4.92 & Yes & $* * * *$ & $<0.0001$ \\
\hline NED $150{ }^{\circ} \mathrm{C}$ WPB vs. Acid $2 \%$ WPD & -5.12 & Yes & $* * * *$ & $<0.0001$ \\
\hline NED $150{ }^{\circ} \mathrm{C}$ WPB vs. Acid 3\% WPD & -3.32 & Yes & $* * * *$ & $<0.0001$ \\
\hline NED $150{ }^{\circ} \mathrm{C}$ WPB vs. Acid $4 \%$ WPD & -5.42 & Yes & $* * * *$ & $<0.0001$ \\
\hline NED $170^{\circ} \mathrm{C}$ WPB vs. NED $150^{\circ} \mathrm{C}$ WPD & -4.36 & Yes & $* * * *$ & $<0.0001$ \\
\hline NED $170{ }^{\circ} \mathrm{C}$ WPB vs. NED $170{ }^{\circ} \mathrm{C}$ WPD & -2.85 & Yes & $* * * *$ & $<0.0001$ \\
\hline NED $170^{\circ} \mathrm{C}$ WPB vs. NED $190^{\circ} \mathrm{C}$ WPD & -3.66 & Yes & $* * * *$ & $<0.0001$ \\
\hline NED $170{ }^{\circ} \mathrm{C}$ WPB vs. NED $200^{\circ} \mathrm{C}$ WPD & -5.14 & Yes & $* * * *$ & $<0.0001$ \\
\hline NED $170{ }^{\circ} \mathrm{C}$ WPB vs. Acid 1\% WPB & 3.27 & Yes & $* * * *$ & $<0.0001$ \\
\hline NED $170{ }^{\circ} \mathrm{C}$ WPB vs. Acid $2 \%$ WPB & -1.79 & Yes & * & 0.0164 \\
\hline NED $170{ }^{\circ} \mathrm{C}$ WPB vs. Acid 3\% WPB & -1.94 & Yes & $* *$ & 0.0058 \\
\hline NED $170{ }^{\circ} \mathrm{C}$ WPB vs. Acid $1 \%$ WPD & -2.56 & Yes & $* * * *$ & $<0.0001$ \\
\hline NED $170{ }^{\circ} \mathrm{C}$ WPB vs. Acid $2 \%$ WPD & -2.76 & Yes & $* * * *$ & $<0.0001$ \\
\hline NED $170{ }^{\circ} \mathrm{C}$ WPB vs. Acid $4 \%$ WPD & -3.06 & Yes & $* * * *$ & $<0.0001$ \\
\hline NED $190^{\circ} \mathrm{C}$ WPB vs. NED $150^{\circ} \mathrm{C}$ WPD & -3.7 & Yes & $* * * *$ & $<0.0001$ \\
\hline NED $190^{\circ} \mathrm{C}$ WPB vs. NED $170{ }^{\circ} \mathrm{C}$ WPD & -2.19 & Yes & $* * *$ & 0.0009 \\
\hline NED $190^{\circ} \mathrm{C}$ WPB vs. NED $190^{\circ} \mathrm{C}$ WPD & -3 & Yes & $* * * *$ & $<0.0001$ \\
\hline NED $190^{\circ} \mathrm{C}$ WPB vs. NED $200^{\circ} \mathrm{C}$ WPD & -4.48 & Yes & $* * * *$ & $<0.0001$ \\
\hline NED $190^{\circ} \mathrm{C}$ WPB vs. Acid 1\% WPB & 3.93 & Yes & $* * * *$ & $<0.0001$ \\
\hline NED $190{ }^{\circ} \mathrm{C}$ WPB vs. Acid $1 \%$ WPD & -1.9 & Yes & $* *$ & 0.0077 \\
\hline NED $190{ }^{\circ} \mathrm{C}$ WPB vs. Acid $2 \%$ WPD & -2.1 & Yes & $* *$ & 0.0018 \\
\hline NED $190{ }^{\circ} \mathrm{C}$ WPB vs. Acid 4\% WPD & -2.4 & Yes & $* * *$ & 0.0002 \\
\hline NED $200^{\circ} \mathrm{C}$ WPB vs. NED $150^{\circ} \mathrm{C}$ WPD & -2.77 & Yes & $* * * *$ & $<0.0001$ \\
\hline NED $200^{\circ} \mathrm{C}$ WPB vs. NED $190^{\circ} \mathrm{C}$ WPD & -2.07 & Yes & $* *$ & 0.0022 \\
\hline NED $200^{\circ} \mathrm{C}$ WPB vs. NED $200^{\circ} \mathrm{C}$ WPD & -3.55 & Yes & $* * * *$ & $<0.0001$ \\
\hline NED $200{ }^{\circ} \mathrm{C}$ WPB vs. Acid 1\% WPB & 4.86 & Yes & $* * * *$ & $<0.0001$ \\
\hline NED $150{ }^{\circ} \mathrm{C}$ WPD vs. Acid $1 \%$ WPB & 7.63 & Yes & $* * * *$ & $<0.0001$ \\
\hline NED $150{ }^{\circ} \mathrm{C}$ WPD vs. Acid $2 \%$ WPB & 2.57 & Yes & $* * * *$ & $<0.0001$ \\
\hline NED $150{ }^{\circ} \mathrm{C}$ WPD vs. Acid 3\% WPB & 2.42 & Yes & $* * *$ & 0.0001 \\
\hline NED $150{ }^{\circ} \mathrm{C}$ WPD vs. Acid $4 \%$ WPB & 3.92 & Yes & $* * * *$ & $<0.0001$ \\
\hline NED $150{ }^{\circ} \mathrm{C}$ WPD vs. Acid $1 \%$ WPD & 1.8 & Yes & * & 0.0154 \\
\hline NED $150{ }^{\circ} \mathrm{C}$ WPD vs. Acid 3\% WPD & 3.4 & Yes & $* * * *$ & $<0.0001$ \\
\hline NED $170{ }^{\circ} \mathrm{C}$ WPD vs. NED $200{ }^{\circ} \mathrm{C}$ WPD & -2.29 & Yes & $* * *$ & 0.0004 \\
\hline NED $170{ }^{\circ} \mathrm{C}$ WPD vs. Acid 1\% WPB & 6.12 & Yes & $* * * *$ & $<0.0001$ \\
\hline NED $170{ }^{\circ} \mathrm{C}$ WPD vs. Acid $4 \%$ WPB & 2.41 & Yes & $* * *$ & 0.0002 \\
\hline NED $170{ }^{\circ} \mathrm{C}$ WPD vs. Acid 3\% WPD & 1.89 & Yes & $* *$ & 0.0083 \\
\hline NED $190{ }^{\circ} \mathrm{C}$ WPD vs. Acid 1\% WPB & 6.93 & Yes & $* * * *$ & $<0.0001$ \\
\hline NED $190{ }^{\circ} \mathrm{C}$ WPD vs. Acid 2\% WPB & 1.87 & Yes & $* *$ & 0.0095 \\
\hline NED $190{ }^{\circ} \mathrm{C}$ WPD vs. Acid 3\% WPB & 1.72 & Yes & * & 0.026 \\
\hline NED $190{ }^{\circ} \mathrm{C}$ WPD vs. Acid $4 \%$ WPB & 3.22 & Yes & $* * * *$ & $<0.0001$ \\
\hline NED $190^{\circ} \mathrm{C}$ WPD vs. Acid 3\% WPD & 2.7 & Yes & $* * * *$ & $<0.0001$ \\
\hline
\end{tabular}


Table A2. Cont.

\begin{tabular}{|c|c|c|c|c|}
\hline Dunn's Multiple Comparisons Test & Mean Rank Diff. & Significant? & Summary & Adjusted $p$ Value \\
\hline NED $200{ }^{\circ} \mathrm{C}$ WPD vs. Acid $1 \%$ WPB & 8.41 & Yes & $* * * *$ & $<0.0001$ \\
\hline NED $200{ }^{\circ} \mathrm{C}$ WPD vs. Acid $\% \%$ WPB & 3.35 & Yes & $* * * *$ & $<0.0001$ \\
\hline NED $200{ }^{\circ} \mathrm{C}$ WPD vs. Acid 3\% WPB & 3.2 & Yes & $* * * *$ & $<0.0001$ \\
\hline NED $200{ }^{\circ} \mathrm{C}$ WPD vs. Acid $4 \%$ WPB & 4.7 & Yes & $* * * *$ & $<0.0001$ \\
\hline NED $200^{\circ} \mathrm{C}$ WPD vs. Acid $1 \%$ WPD & 2.58 & Yes & $* * * *$ & $<0.0001$ \\
\hline NED $200^{\circ} \mathrm{C}$ WPD vs. Acid $2 \%$ WPD & 2.38 & Yes & $* * *$ & 0.0002 \\
\hline NED $200^{\circ} \mathrm{C}$ WPD vs. Acid $3 \%$ WPD & 4.18 & Yes & $* * * *$ & $<0.0001$ \\
\hline NED $200{ }^{\circ} \mathrm{C}$ WPD vs. Acid $4 \%$ WPD & 2.08 & Yes & $* *$ & 0.0021 \\
\hline Acid $1 \%$ WPB vs. Acid 2\% WPB & -5.06 & Yes & $* * * *$ & $<0.0001$ \\
\hline Acid 1\% WPB vs. Acid 3\% WPB & -5.21 & Yes & $* * * *$ & $<0.0001$ \\
\hline Acid 1\% WPB vs. Acid 4\% WPB & -3.71 & Yes & $* * * *$ & $<0.0001$ \\
\hline Acid $1 \%$ WPB vs. Acid $1 \%$ WPD & -5.83 & Yes & $* * * *$ & $<0.0001$ \\
\hline Acid $1 \%$ WPB vs. Acid $2 \%$ WPD & -6.03 & Yes & $* * * *$ & $<0.0001$ \\
\hline Acid $1 \%$ WPB vs. Acid 3\% WPD & -4.23 & Yes & $* * * *$ & $<0.0001$ \\
\hline Acid $1 \%$ WPB vs. Acid $4 \%$ WPD & -6.33 & Yes & $* * * *$ & $<0.0001$ \\
\hline Acid $4 \%$ WPB vs. Acid $1 \%$ WPD & -2.12 & Yes & $* *$ & 0.0015 \\
\hline Acid $4 \%$ WPB vs. Acid $2 \%$ WPD & -2.32 & Yes & $* * *$ & 0.0003 \\
\hline Acid $4 \%$ WPB vs. Acid $4 \%$ WPD & -2.62 & Yes & $* * * *$ & $<0.0001$ \\
\hline Acid $2 \%$ WPD vs. Acid 3\% WPD & 1.8 & Yes & * & 0.0154 \\
\hline Acid 3\% WPD vs. Acid 4\% WPD & -2.1 & Yes & $* *$ & 0.0018 \\
\hline
\end{tabular}

Table A3. Two-way ANOVA, Tukey's multiple comparisons test, for ethanol yields.

\begin{tabular}{|c|c|c|c|c|}
\hline Dunn's Multiple Comparisons Test & Mean Rank Diff. & Significant? & Summary & Adjusted $p$ Value \\
\hline NED $150{ }^{\circ} \mathrm{C}$ WPB vs. NED $200{ }^{\circ} \mathrm{C}$ WPB & -2.02 & Yes & $* *$ & 0.0032 \\
\hline NED $150{ }^{\circ} \mathrm{C}$ WPB vs. NED $150^{\circ} \mathrm{C}$ WPD & -4.12 & Yes & $* * * *$ & $<0.0001$ \\
\hline $\mathrm{NED} 150^{\circ} \mathrm{C}$ WPB vs. NED $170^{\circ} \mathrm{C}$ WPD & -3.28 & Yes & $* * * *$ & $<0.0001$ \\
\hline NED $150^{\circ} \mathrm{C}$ WPB vs. NED $190^{\circ} \mathrm{C}$ WPD & -3.69 & Yes & $* * * *$ & $<0.0001$ \\
\hline NED $150^{\circ} \mathrm{C}$ WPB vs. NED $200^{\circ} \mathrm{C}$ WPD & -4.33 & Yes & $* * * *$ & $<0.0001$ \\
\hline NED $150{ }^{\circ} \mathrm{C}$ WPB vs. Acid 2\% WPB & -2.16 & Yes & $* *$ & 0.0011 \\
\hline NED $150{ }^{\circ} \mathrm{C}$ WPB vs. Acid 3\% WPB & -1.9 & Yes & $* *$ & 0.0077 \\
\hline NED $150{ }^{\circ} \mathrm{C}$ WPB vs. Acid $1 \%$ WPD & -2.67 & Yes & $* * * *$ & $<0.0001$ \\
\hline NED $150{ }^{\circ} \mathrm{C}$ WPB vs. Acid $2 \%$ WPD & -2.87 & Yes & $* * * *$ & $<0.0001$ \\
\hline NED $150{ }^{\circ} \mathrm{C}$ WPB vs. Acid $3 \%$ WPD & -1.87 & Yes & $* *$ & 0.0095 \\
\hline NED $150{ }^{\circ} \mathrm{C}$ WPB vs. Acid 4\% WPD & -3.07 & Yes & $* * * *$ & $<0.0001$ \\
\hline NED $170{ }^{\circ} \mathrm{C}$ WPB vs. NED $150^{\circ} \mathrm{C}$ WPD & -3.06 & Yes & $* * * *$ & $<0.0001$ \\
\hline NED $170^{\circ} \mathrm{C}$ WPB vs. NED $170^{\circ} \mathrm{C}$ WPD & -2.22 & Yes & $* * *$ & 0.0007 \\
\hline $\mathrm{NED} 170^{\circ} \mathrm{C}$ WPB vs. NED $190^{\circ} \mathrm{C}$ WPD & -2.63 & Yes & $* * * *$ & $<0.0001$ \\
\hline NED $170^{\circ} \mathrm{C}$ WPB vs. NED $200^{\circ} \mathrm{C}$ WPD & -3.27 & Yes & $* * * *$ & $<0.0001$ \\
\hline NED $170{ }^{\circ} \mathrm{C}$ WPB vs. Acid $2 \%$ WPD & -1.81 & Yes & * & 0.0143 \\
\hline NED $170{ }^{\circ} \mathrm{C}$ WPB vs. Acid $4 \%$ WPD & -2.01 & Yes & $* *$ & 0.0035 \\
\hline NED $190^{\circ} \mathrm{C}$ WPB vs. NED $150^{\circ} \mathrm{C}$ WPD & -2.62 & Yes & $* * * *$ & $<0.0001$ \\
\hline NED $190^{\circ} \mathrm{C}$ WPB vs. NED $170^{\circ} \mathrm{C}$ WPD & -1.78 & Yes & * & 0.0176 \\
\hline NED $190^{\circ} \mathrm{C}$ WPB vs. NED $190^{\circ} \mathrm{C}$ WPD & -2.19 & Yes & $* * *$ & 0.0009 \\
\hline NED $190^{\circ} \mathrm{C}$ WPB vs. NED $200^{\circ} \mathrm{C}$ WPD & -2.83 & Yes & $* * * *$ & $<0.0001$ \\
\hline NED $190^{\circ} \mathrm{C}$ WPB vs. Acid 1\% WPB & 1.73 & Yes & * & 0.0244 \\
\hline
\end{tabular}


Table A3. Cont.

\begin{tabular}{|c|c|c|c|c|}
\hline Dunn's Multiple Comparisons Test & Mean Rank Diff. & Significant? & Summary & Adjusted $p$ Value \\
\hline NED $200{ }^{\circ} \mathrm{C}$ WPB vs. NED $150{ }^{\circ} \mathrm{C}$ WPD & -2.1 & Yes & ** & 0.0018 \\
\hline NED $200{ }^{\circ} \mathrm{C}$ WPB vs. NED $190^{\circ} \mathrm{C}$ WPD & -1.67 & Yes & * & 0.0357 \\
\hline NED $200{ }^{\circ} \mathrm{C}$ WPB vs. NED $200{ }^{\circ} \mathrm{C}$ WPD & -2.31 & Yes & $* * *$ & 0.0003 \\
\hline NED $200^{\circ} \mathrm{C}$ WPB vs. Acid 1\% WPB & 2.25 & Yes & $* * *$ & 0.0006 \\
\hline NED $150{ }^{\circ} \mathrm{C}$ WPD vs. Acid 1\% WPB & 4.35 & Yes & $* * * *$ & $<0.0001$ \\
\hline NED $150{ }^{\circ} \mathrm{C}$ WPD vs. Acid $2 \%$ WPB & 1.96 & Yes & $* *$ & 0.005 \\
\hline NED $150{ }^{\circ} \mathrm{C}$ WPD vs. Acid 3\% WPB & 2.22 & Yes & $* * *$ & 0.0007 \\
\hline NED $150{ }^{\circ} \mathrm{C}$ WPD vs. Acid $4 \%$ WPB & 2.92 & Yes & $* * * *$ & $<0.0001$ \\
\hline NED $150{ }^{\circ} \mathrm{C}$ WPD vs. Acid 3\% WPD & 2.25 & Yes & $* * *$ & 0.0006 \\
\hline NED $170{ }^{\circ} \mathrm{C}$ WPD vs. Acid $1 \%$ WPB & 3.51 & Yes & $* * * *$ & $<0.0001$ \\
\hline NED $170{ }^{\circ} \mathrm{C}$ WPD vs. Acid $4 \%$ WPB & 2.08 & Yes & $* *$ & 0.0021 \\
\hline NED $190{ }^{\circ} \mathrm{C}$ WPD vs. Acid 1\% WPB & 3.92 & Yes & $* * * *$ & $<0.0001$ \\
\hline NED $190{ }^{\circ} \mathrm{C}$ WPD vs. Acid 3\% WPB & 1.79 & Yes & * & 0.0164 \\
\hline NED $190{ }^{\circ} \mathrm{C}$ WPD vs. Acid $4 \%$ WPB & 2.49 & Yes & $* * * *$ & $<0.0001$ \\
\hline NED $190^{\circ} \mathrm{C}$ WPD vs. Acid 3\% WPD & 1.82 & Yes & $*$ & 0.0134 \\
\hline NED $200{ }^{\circ} \mathrm{C}$ WPD vs. Acid $1 \%$ WPB & 4.56 & Yes & $* * * *$ & $<0.0001$ \\
\hline NED $200{ }^{\circ} \mathrm{C}$ WPD vs. Acid $2 \%$ WPB & 2.17 & Yes & $* *$ & 0.001 \\
\hline NED $200{ }^{\circ} \mathrm{C}$ WPD vs. Acid 3\% WPB & 2.43 & Yes & $* * *$ & 0.0001 \\
\hline NED $200{ }^{\circ} \mathrm{C}$ WPD vs. Acid $4 \%$ WPB & 3.13 & Yes & $* * * *$ & $<0.0001$ \\
\hline NED $200^{\circ} \mathrm{C}$ WPD vs. Acid 1\% WPD & 1.66 & Yes & * & 0.038 \\
\hline NED $200^{\circ} \mathrm{C}$ WPD vs. Acid 3\% WPD & 2.46 & Yes & $* * *$ & 0.0001 \\
\hline Acid $1 \%$ WPB vs. Acid $2 \%$ WPB & -2.39 & Yes & $* * *$ & 0.0002 \\
\hline Acid 1\% WPB vs. Acid 3\% WPB & -2.13 & Yes & $* *$ & 0.0014 \\
\hline Acid $1 \%$ WPB vs. Acid $1 \%$ WPD & -2.9 & Yes & $* * * *$ & $<0.0001$ \\
\hline Acid $1 \%$ WPB vs. Acid $2 \%$ WPD & -3.1 & Yes & $* * * *$ & $<0.0001$ \\
\hline Acid $1 \%$ WPB vs. Acid 3\% WPD & -2.1 & Yes & $* *$ & 0.0018 \\
\hline Acid $1 \%$ WPB vs. Acid 4\% WPD & -3.3 & Yes & $* * * *$ & $<0.0001$ \\
\hline Acid $4 \%$ WPB vs. Acid $2 \%$ WPD & -1.67 & Yes & $*$ & 0.0357 \\
\hline Acid $4 \%$ WPB vs. Acid $4 \%$ WPD & -1.87 & Yes & $* *$ & 0.0095 \\
\hline
\end{tabular}

${ }^{*} p \leq 0.05,{ }^{* *} p \leq 0.01,{ }^{* * *} p \leq 0.001,{ }^{* * * *} p \leq 0.0001$.

Table A4. One-way ANOVA, Dunn's multiple comparisons test, for biomethane results.

\begin{tabular}{|c|c|c|c|c|}
\hline Dunn's Multiple Comparisons Test & Mean Rank Diff. & Significant? & Summary & Adjusted $p$ Value \\
\hline Untreated WPD vs. NED $200^{\circ} \mathrm{C}$ WPD & -225.6 & Yes & $* * * *$ & $<0.0001$ \\
\hline Untreated WPD vs. Acid 2\% WPD & -235.7 & Yes & $* * * *$ & $<0.0001$ \\
\hline Untreated WPD vs. Acid 3\% WPD & -223.3 & Yes & $* * * *$ & $<0.0001$ \\
\hline Untreated WPD vs. NED $150{ }^{\circ} \mathrm{C}$ WPB & -176.6 & Yes & $* *$ & 0.006 \\
\hline Untreated WPD vs. NED $190^{\circ} \mathrm{C}$ WPB & -164.1 & Yes & * & 0.0204 \\
\hline Untreated WPD vs. Acid 4\% WPB & -159.7 & Yes & * & 0.0307 \\
\hline NED $150{ }^{\circ} \mathrm{C}$ WPD vs. Acid $\%$ WPB & 195.6 & Yes & $* * *$ & 0.0008 \\
\hline NED $170{ }^{\circ} \mathrm{C}$ WPD vs. Acid $2 \%$ WPB & 186.5 & Yes & $* *$ & 0.0022 \\
\hline NED $190{ }^{\circ} \mathrm{C}$ WPD vs. Acid $1 \%$ WPB & 167.2 & Yes & * & 0.0152 \\
\hline NED $190{ }^{\circ} \mathrm{C}$ WPD vs. Acid $2 \%$ WPB & 223.6 & Yes & $* * * *$ & $<0.0001$ \\
\hline NED $200^{\circ} \mathrm{C}$ WPD vs. Acid 1\% WPD & 182.5 & Yes & $* *$ & 0.0033 \\
\hline NED $200^{\circ} \mathrm{C}$ WPD vs. Untreated WPB & 173 & Yes & $* *$ & 0.0087 \\
\hline NED $200^{\circ} \mathrm{C}$ WPD vs. NED $170^{\circ} \mathrm{C}$ WPB & 233.3 & Yes & $* * * *$ & $<0.0001$ \\
\hline NED $200{ }^{\circ} \mathrm{C}$ WPD vs. NED $200{ }^{\circ} \mathrm{C}$ WPB & 211.9 & Yes & $* * *$ & 0.0001 \\
\hline NED $200^{\circ} \mathrm{C}$ WPD vs. Acid 1\% WPB & 273.6 & Yes & $* * * *$ & $<0.0001$ \\
\hline NED $200{ }^{\circ} \mathrm{C}$ WPD vs. Acid $2 \%$ WPB & 330.1 & Yes & $* * * *$ & $<0.0001$ \\
\hline
\end{tabular}


Table A4. Cont.

\begin{tabular}{|c|c|c|c|c|}
\hline Dunn's Multiple Comparisons Test & Mean Rank Diff. & Significant? & Summary & Adjusted $p$ Value \\
\hline Acid $1 \%$ WPD vs. Acid $2 \%$ WPD & -192.6 & Yes & $* *$ & 0.0013 \\
\hline Acid 1\% WPD vs. Acid 3\% WPD & -180.2 & Yes & $* *$ & 0.0048 \\
\hline Acid 2\% WPD vs. Untreated WPB & 183.1 & Yes & $* *$ & 0.0036 \\
\hline Acid $2 \%$ WPD vs. NED $170^{\circ} \mathrm{C} W P B$ & 243.4 & Yes & $* * * *$ & $<0.0001$ \\
\hline Acid $2 \%$ WPD vs. NED $200^{\circ} \mathrm{C}$ WPB & 222 & Yes & $* * * *$ & $<0.0001$ \\
\hline Acid 2\% WPD vs. Acid 1\% WPB & 283.7 & Yes & $* * * *$ & $<0.0001$ \\
\hline Acid $2 \%$ WPD vs. Acid 2\% WPB & 340.2 & Yes & $* * * *$ & $<0.0001$ \\
\hline Acid 3\% WPD vs. Untreated WPB & 170.7 & Yes & * & 0.0122 \\
\hline Acid $3 \%$ WPD vs. NED $170^{\circ} \mathrm{C}$ WPB & 231 & Yes & $* * * *$ & $<0.0001$ \\
\hline Acid $3 \%$ WPD vs. NED $200^{\circ} \mathrm{C}$ WPB & 209.6 & Yes & $* * *$ & 0.0002 \\
\hline Acid 3\% WPD vs. Acid 1\% WPB & 271.3 & Yes & $* * * *$ & $<0.0001$ \\
\hline Acid 3\% WPD vs. Acid 2\% WPB & 327.8 & Yes & $* * * *$ & $<0.0001$ \\
\hline Acid $4 \%$ WPD vs. NED $170^{\circ} \mathrm{C}$ WPB & 156.9 & Yes & $*$ & 0.0439 \\
\hline Acid 4\% WPD vs. Acid 1\% WPB & 197.2 & Yes & $* * *$ & 0.0008 \\
\hline Acid 4\% WPD vs. Acid 2\% WPB & 253.7 & Yes & $* * * *$ & $<0.0001$ \\
\hline Untreated WPB vs. Acid 2\% WPB & 157.1 & Yes & * & 0.0432 \\
\hline NED $150{ }^{\circ} \mathrm{C}$ WPB vs. NED $170{ }^{\circ} \mathrm{C}$ WPB & 184.3 & Yes & ** & 0.0031 \\
\hline NED $150{ }^{\circ} \mathrm{C}$ WPB vs. NED $200{ }^{\circ} \mathrm{C}$ WPB & 162.9 & Yes & * & 0.0255 \\
\hline NED $150{ }^{\circ} \mathrm{C}$ WPB vs. Acid 1\% WPB & 224.6 & Yes & $* * * *$ & $<0.0001$ \\
\hline NED $150{ }^{\circ} \mathrm{C}$ WPB vs. Acid 2\% WPB & 281.1 & Yes & $* * * *$ & $<0.0001$ \\
\hline NED $170{ }^{\circ} \mathrm{C}$ WPB vs. NED $190{ }^{\circ} \mathrm{C}$ WPB & -171.8 & Yes & * & 0.011 \\
\hline NED $170{ }^{\circ} \mathrm{C}$ WPB vs. Acid 4\% WPB & -167.4 & Yes & * & 0.0168 \\
\hline NED $190^{\circ} \mathrm{C}$ WPB vs. Acid 1\% WPB & 212.1 & Yes & $* * *$ & 0.0001 \\
\hline NED $190{ }^{\circ} \mathrm{C}$ WPB vs. Acid 2\% WPB & 268.6 & Yes & $* * * *$ & $<0.0001$ \\
\hline Acid 1\% WPB vs. Acid 3\% WPB & -181.5 & Yes & $* *$ & 0.0042 \\
\hline Acid 1\% WPB vs. Acid 4\% WPB & -207.7 & Yes & $* * *$ & 0.0002 \\
\hline Acid 2\% WPB vs. Acid 3\% WPB & -237.9 & Yes & $* * * *$ & $<0.0001$ \\
\hline Acid $2 \%$ WPB vs. Acid 4\% WPB & -264.1 & Yes & $* * * *$ & $<0.0001$ \\
\hline
\end{tabular}

${ }^{*} p \leq 0.05,{ }^{* *} p \leq 0.01,{ }^{* * *} p \leq 0.001,{ }^{* * * *} p \leq 0.0001$.

\section{References}

1. Dabe, S.; Prasad, P.; Vaidya, A.; Purohit, H. Technological pathways for bioenergy generation from municipal solid waste: Renewable energy option. Environ. Prog. Sustain. Energy 2019, 38, 654-671. [CrossRef]

2. Bakraoui, M.; Hazzi, M.; Karouach, F.; Ouhammou, B.; El Bari, H. Experimental biogas production from recycled pulp and paper wastewater by biofilm technology. Biotechnol. Lett. 2019, 41, 1299-1307. [CrossRef] [PubMed]

3. Sanchis-Sebastiá, M.; Gomis-Fons, J.; Galbe, M.; Wallberg, O. Techno-Economic Evaluation of Biorefineries Based on Low-Value Feedstocks Using the BioSTEAM Software: A Case Study for Animal Bedding. Processes 2020, 8, 904. [CrossRef]

4. Brown, A.; Waldheim, L.; Landälv, I.; Saddler, J.; Ebadian, M.; McMillan, J.D.; Bonomi, A.; Klein, B. Advanced Biofuels-Potential for Cost Reduction. IEA Bioenergy 2020, 88.

5. Ameli, M.; Mansour, S.; Ahmadi-Javid, A. A simulation-optimization model for sustainable product design and efficient end-of-life management based on individual producer responsibility. Resour. Conserv. Recycl. 2019, 140, 246-258. [CrossRef]

6. Luján-Ornelas, C.; del Mancebo, C.; Sternenfels, U.; Güereca, L.P. Life cycle assessment of Mexican polymer and high-durability cotton paper banknotes. Sci. Total Environ. 2018, 630, 409-421.

7. Yehia, A.; Yassin, K.; Eid, A. Recycling of shredded currency waste of Egyptian Central Bank for making good-quality papers. Sep. Sci.Technol. 2017, 53, 1-7. [CrossRef]

8. Sunil, S.; Panchmal, G.; Shenoy, R.; Kumar, V.; Jodalli, P.; Somaraj, V. Assessment of microbial contamination of indian currency notes in circulation. J. Indian Assoc. Public Health Dent. 2020, 18, 179-182. [CrossRef]

9. Sheikh, M.M.; Kim, C.H.; Park, H.J.; Kim, S.H.; Kim, G.C.; Lee, J.Y.; Sim, S.W.; Kim, J.W. Alkaline pretreatment improves saccharification and ethanol yield from waste money bills. Biosci. Biotechnol. Biochem. 2013, 77, 1397-1402. [CrossRef]

10. Zhang, Q.; Khan, M.U.; Lin, X.; Yi, W.; Lei, H. Green-composites produced from waste residue in pulp and paper industry: A sustainable way to manage industrial wastes. J. Clean. Prod. 2020, 262, 121251. [CrossRef] 
11. Parra, R.; Vargas-Radillo, J.; Arzate, F.; Quiñones, J.; Aguilar, B.; Valdovinos, E.; Casillas, R. Ultrasonic treatment for deinking of laser paper using two frequencies, 25 and $45 \mathrm{khz}$ (Destintado de papel de impresión láser mediante ultrasonido con dos frecuencias, 25 y $45 \mathrm{kHz}$ ). Rev. Mex. Cienc. For. 2015, 6, 126-141.

12. Carré, B.; Magnin, L.; Galland, G. Deinking difficulties related to ink formulation, printing process, and type of paper. Tappi J. 2000, 83, 60 .

13. Ferguson, L.D. Deinking chemistry Part. 1. Tappi J. 1992, 75, 75-83.

14. Raud, M.; Kikas, T.; Sippula, O.; Shurpali, N.J. Potentials and challenges in lignocellulosic biofuel production technology. Renew. Sustain. Energy Rev. 2019, 111, 44-56. [CrossRef]

15. Rocha-Meneses, L.; Raud, M.; Orupõld, K.; Kikas, T. Second-generation bioethanol production: A review of strategies for waste valorisation. Agron. Res. 2017, 15, 830-847.

16. Rooni, V.; Raud, M.; Kikas, T. Technical solutions used in different pretreatments of lignocellulosic biomass: A review. Agron. Res. 2017, 15, 848-858.

17. Megala, S.; Rekha, B.; Saravanathamizhan, R. Chemical and non-chemical pre-treatment techniques for bio ethanol production from biomass. Int. J. Energy Water Resour. 2020, 4, 199-204. [CrossRef]

18. Raud, M.; Orupõld, K.; Rocha-Meneses, L.; Rooni, V.; Träss, O.; Kikas, T. Biomass Pretreatment with the Szego Mill ${ }^{\mathrm{TM}}$ for Bioethanol and Biogas Production. Processes 2020, 8, 1327. [CrossRef]

19. Shirkavand, E.; Baroutian, S.; Gapes, D.J.; Young, B.R. Combination of fungal and physicochemical processes for lignocellulosic biomass pretreatment-A review. Renew. Sustain. Energy Rev. 2016, 54, 217-234. [CrossRef]

20. Rocha-Meneses, L.; Raud, M.; Orupõld, K.; Kikas, T. Potential of bioethanol production waste for methane recovery. Energy 2019, 173, 133-139. [CrossRef]

21. Raud, M.; Olt, J.; Kikas, T. N2 explosive decompression pretreatment of biomass for lignocellulosic ethanol production. Biomass Bioenergy 2016, 90, 1-6. [CrossRef]

22. Rodriguez, C.; Alaswad, A.; El-Hassan, Z.; Olabi, A.G. Mechanical pretreatment of waste paper for biogas production. Waste Manag. 2017, 68, 157-164. [CrossRef] [PubMed]

23. Manyi-Loh, C.E.; Mamphweli, S.N.; Meyer, E.L.; Okoh, A.I.; Makaka, G.; Simon, M. Microbial anaerobic digestion (bio-digesters) as an approach to the decontamination of animal wastes in pollution control and the generation of renewable energy. Int. J. Environ. Res. Public Health 2013, 10, 4390-4417. [CrossRef]

24. Rocha-Meneses, L.; Ivanova, A.; Atouguia, G.; Avila, I.; Raud, M.; Orupold, K.; Kikas, T. The effect of flue gas explosive decompression pretreatment on methane recovery from bioethanol production waste. Industri Crops Prod. 2019, 127, 66-72 [CrossRef]

25. Test Method TAPPI/ANSI T 456 om-15. Tensile Breaking Strength of Water-Saturated Paper and Paperboard ("Wet Tensile Strength"). Standard Method; Technical Association of the Pulp and Paper Industry: Peachtree Corners, GA, USA, 2015.

26. Aghmashhadi, O.Y.; Asadpour, G.; Garmaroody, E.R.; Zabihzadeh, M.; Rocha-Meneses, L.; Kikas, T. The Effect of Deinking Process. on Bioethanol Production from Waste Banknote Paper. Processes 2020, 8, 1563.

27. Chatrath, H.; Durge, R. Repulping of Waste Paper Containing High Wet Strength. IUP J. Sci. Technol. $2011,7$.

28. Rocha Meneses, L.; Orupõld, K.; Kikas, T. Potential of bioethanol production waste for methane recovery (short version). In Proceedings of the 11th International Conference on Sustainable Energy \& Environmental Protection, Paisley, UK, 8-11 May 2018.

29. Angelidaki, I.; Treu, L.; Tsapekos, P.; Luo, G.; Campanaro, S.; Wenzel, H.; Kougias, P.G. Biogas upgrading and utilization: Current status and perspectives. Biotechnol. Adv. 2018, 36, 452-466. [CrossRef]

30. Raud, M.; Rooni, V.; Kikas, T. The Efficiency of Nitrogen and Flue Gas as Operating Gases in Explosive Decompression Pretreatment. Energies 2018, 11, 2074. [CrossRef]

31. Yousef, S.; Eimontas, J.; Striūgas, N.; Trofimov, E.; Hamdy, M.; Abdelnaby, M.A. Conversion of end-of-life cotton banknotes into liquid fuel using mini-pyrolysis plant. J. Clean. Prod. 2020, 267, 121612. [CrossRef]

32. Rocha-Meneses, L.; Otor, O.F.; Bonturi, N.; Orupõld, K.; Kikas, T. Bioenergy Yields from Sequential Bioethanol and Biomethane Production: An Optimized Process Flow. Sustainability 2020, 12, 272. [CrossRef]

33. Rocha-Meneses, L.; Ferreira, J.A.; Bonturi, N.; Orupõld, K.; Kikas, T. Enhancing Bioenergy Yields from Sequential Bioethanol and Biomethane Production by Means of Solid-Liquid Separation of the Substrates. Energies 2019, 12, 3683. [CrossRef]

34. Jeihanipour, A.; Taherzadeh, M.J. Ethanol production from cotton-based waste textiles. Bioresour. Technol. 2009, 100, 1007-1010. [CrossRef] [PubMed]

35. Montgomery, L.F.R.; Bochmann, G. Pretreatment of Feedstock for Enhanced Biogas Production. In IEA Bioenergy Task 37-Energy from Biogas; Baxter, D., Ed.; IEA Bioenergy: Paris, France, 2014; ISBN 978-1-910154-05-2.

36. Phuttaro, C.; Sawatdeenarunat, C.; Surendra, K.C.; Boonsawang, P.; Chaiprapat, S.; Khanal, S.K. Anaerobic digestion of hydrothermally-pretreated lignocellulosic biomass: Influence of pretreatment temperatures, inhibitors and soluble organics on methane yield. Bioresour. Technol. 2019, 284, 128-138. [CrossRef] [PubMed]

37. Pilli, S.; Yan, S.; Tyagi, R.D.; Surampalli, R.Y. Thermal Pretreatment of Sewage Sludge to Enhance Anaerobic Digestion: A Review. Crit. Rev. Environ. Sci. Technol. 2015, 45, 669-702. [CrossRef]

38. Sjulander, N.; Kikas, T. Origin, Impact and Control of Lignocellulosic Inhibitors in Bioethanol Production-A Review. Energies 2020, 13, 4751. [CrossRef] 
39. Sarto, S.; Hildayati, R.; Syaichurrozi, I. Effect of chemical pretreatment using sulfuric acid on biogas production from water hyacinth and kinetics. Renew. Energy 2019, 132, 335-350. [CrossRef]

40. Patinvoh, R.J.; Osadolor, O.A.; Chandolias, K.; Sárvári Horváth, I.; Taherzadeh, M.J. Innovative pretreatment strategies for biogas production. Bioresour. Technol. 2017, 224, 13-24. [CrossRef]

41. Venturin, B.; Frumi Camargo, A.; Scapini, T.; Mulinari, J.; Bonatto, C.; Bazoti, S.; Pereira Siqueira, D.; Maria Colla, L.; Alves, S.L.; Paulo Bender, J.; et al. Effect of pretreatments on corn stalk chemical properties for biogas production purposes. Bioresour. Technol. 2018, 266, 116-124. [CrossRef]

42. Rabie, S.; Rostom, M.; Gaber, M.; Enshasy, H. Treatment of Egyptian wastepaper using flotation technique for recovery of fillers and minerals. Int. J. Sci. Technol. Res. 2020, 9, 3077-3083.

43. Syaichurrozi, I.; Villta, P.K.; Nabilah, N.; Rusdi, R. Effect of sulfuric acid pretreatment on biogas production from Salvinia molesta. J. Environ. Chem. Eng. 2019, 7, 102857. [CrossRef]

44. Antonopoulou, G.; Vayenas, D.; Lyberatos, G. Biogas Production from Physicochemically Pretreated Grass Lawn Waste: Comparison of Different Process. Schemes. Molecules 2020, 25, 296. [CrossRef] [PubMed]

45. Avila, R.; Carrero, E.; Crivillés, E.; Mercader, M.; Vicent, T.; Blánquez, P. Effects of low temperature thermal pretreatments insolubility and co-digestion of waste activated sludge and microalgae mixtures. Algal Res. 2020, 50, 101965. [CrossRef]

46. Wang, L.; Templer, R.; Murphy, R.J. A Life Cycle Assessment (LCA) comparison of three management options for waste papers: Bioethanol production, recycling and incineration with energy recovery. Bioresour. Technol. 2012, 120, 89-98. [CrossRef] [PubMed] 